\title{
Paleoceanography
}

\section{RESEARCH ARTICLE \\ 10.1002/2014PA002724 \\ Evidence for reduced export productivity following the Cretaceous/Paleogene mass extinction}

\section{Key Points:}

- Following the $\mathrm{K} / \mathrm{Pg}$, shelf surfacebottom $\delta{ }^{13} \mathrm{C}$ gradients and TOC accumulation rates collapsed

- Planktonic $\delta{ }^{13} \mathrm{C}$ gradients were maintained and cross-shelf $\delta^{13} \mathrm{C}$ gradients accentuated after the K/Pg - Shelf and deep sea records indicate reduced export productivity (Living Ocean) after the $\mathrm{K} / \mathrm{Pg}$

Supporting Information:

- Texts S1 and S2, Figures S1-S8, and Tables S1 and S2

- Data Set S1

- Data Set S2

- Table S3

- Table S4

- Table S5

Correspondence to:

S. Esmeray-Senlet,

selenesmeray@gmail.com;

esmeray@rutgers.edu

Citation:

Esmeray-Senlet, S., J. D. Wright, R. K. Olsson, K. G. Miller, J. V. Browning, and T. M. Quan (2015), Evidence for reduced export productivity following the Cretaceous/ Paleogene mass extinction, Paleoceanography, 30, 718-738, doi:10.1002/2014PA002724.

Received 25 SEP 2014 Accepted 14 MAY 2015 Accepted article online 19 MAY 2015 Published online 18 JUN 2015

\author{
Selen Esmeray-Senlet ${ }^{1}$, James D. Wright ${ }^{1}$, Richard K. Olsson ${ }^{1}$, Kenneth G. Miller ${ }^{1}$, \\ James V. Browning ${ }^{1}$, and Tracy M. Quan ${ }^{2}$ \\ ${ }^{1}$ Department of Earth and Planetary Sciences, Rutgers University, Piscataway, New Jersey, USA, ${ }^{2}$ Boone Pickens School of \\ Geology, Oklahoma State University, Stillwater, Oklahoma, USA
}

Abstract The Cretaceous/Paleogene $(\mathrm{K} / \mathrm{Pg})$ mass extinction was associated with a collapse in the carbon isotopic $\left(\delta^{13} \mathrm{C}\right)$ gradient between planktonic and benthic foraminifera and a decrease in bulk carbonate $\delta^{13} \mathrm{C}$ values. These perturbations have been explained by several hypotheses: global collapse of primary productivity (Strangelove Ocean), greatly reduced export but not primary productivity (Living Ocean), little or no reduction in export productivity (Resilient Ocean), and geographic heterogeneity in the change of export productivity (Heterogeneous Ocean). We tested primary versus export productivity changes in the paleoshelf of New Jersey, where $\delta^{13} \mathrm{C}$ values and organic carbon accumulation rates can distinguish among different ocean responses. On the shelf, the $\mathrm{K} / \mathrm{Pg}$ boundary is associated with a $\sim 2.5 \%{ }^{13} \mathrm{C}$ decrease in bulk carbonate, a $\sim 0.8 \%{ }_{0} \delta^{13} \mathrm{C}$ decrease in organic carbon, a collapse of the surface to bottom $\delta^{13} \mathrm{C}$ gradient, and a drop in organic carbon accumulation rates. We interpret an early Danian $\sim 1.0 \%$ o planktonic foraminiferal $\delta^{13} \mathrm{Cgradient}$, a $\sim 0.75 \%$ o cross-shelf benthic foraminiferal $\delta^{13} \mathrm{C}$ gradient, and a drop in carbon accumulation rates to reflect the presence of active primary but limited export productivity, consistent with the Living Ocean hypothesis. We evaluated interbasinal deep-sea benthic foraminiferal $\delta^{13} \mathrm{C}$ gradients between the Pacific (Site 1210) and Atlantic (Site 1262) oceans as a proxy for changes in export productivity. The interbasinal $\delta^{13} \mathrm{C}$ gradient was reduced after the mass extinction, suggesting a reduction in global export productivity. Although our data support the Living Ocean hypothesis, evidence from paleoupwelling zones shows significant export productivity, indicating spatial heterogeneity in the wake of the K/Pg mass extinction (Heterogeneous Ocean).

\section{Introduction}

The mass extinction at the Cretaceous/Paleogene $(\mathrm{K} / \mathrm{Pg})$ boundary altered both terrestrial and marine ecosystems with the disappearance of large bodied groups such as non-avian dinosaurs, marine and flying reptiles, ammonites, and rudists [eg., Raup and Sepkoski, 1982; Schulte et al., 2010]. In addition to macrofauna, calcareous plankton suffered catastrophic extinctions, with the disappearance of more than 90\% of Cretaceous species of planktonic foraminifera [Smit, 1982; Olsson and Liu, 1993; Olsson et al., 1999] and calcareous nannofossils [e.g., Bernaola and Monechi, 2007].

The mass extinction is hypothesized to be associated with drastic perturbations in the oceanic carbon cycle as shown by a collapse in the carbon isotopic $\left(\delta^{13} \mathrm{C}\right)$ gradient between surface and deep waters recorded by planktonic and benthic foraminifera, and a significant drop in bulk carbonate $\delta^{13} \mathrm{C}$ values [e.g., Zachos and Arthur, 1986]. The $\delta^{13} \mathrm{C}$ gradient between surface and deep waters is a result of the biological pump, the sinking of organic carbon from the surface ocean and its oxidation at depth [Broecker and Peng, 1982; Volk and Hoffert, 1985]. The export of organic carbon from surface waters produces a surface to bottom vertical $\delta^{13} \mathrm{C}$ gradient [Kroopnick, 1985] because ${ }^{12} \mathrm{C}$ is preferentially used by photosynthetic organisms, causing the $\delta^{13} \mathrm{C}$ of organic carbon to be $\sim 20 \%$ o lower than the $\delta^{13} \mathrm{C}$ of the dissolved inorganic carbon (DIC) in seawater [Degens, 1969]. Therefore, the $\delta^{13} \mathrm{C}$ of DIC in modern surface waters is 1 to 3\%o higher than the $\delta^{13} \mathrm{C}$ of DIC in the deep oceans [Kroopnick, 1985]. Previous studies have shown that the $\delta^{13} \mathrm{C}$ difference between surface-dwelling planktonic and deep-sea benthic foraminiferal tests in the latest Cretaceous was $\sim 2 \%$ [ [D'Hondt, 2005], which is similar to that measured in the modern oceans [Kroopnick, 1985]. However, this difference apparently disappeared at the beginning of the Paleocene [Zachos and Arthur, 1986; Stott and Kennett, 1989; Zachos et al., 1989; D'Hondt and Zachos, 1998; D'Hondt, 2005; Coxall et al., 2006]. The biotic recovery from the mass extinction and the redevelopment of a full $\delta^{13} \mathrm{C}$ gradient between surface and deep waters took more than 3 Myr [D'Hondt and Zachos, 1998; Birch et al., 2012]. The collapse of the 
surface to deep ocean $\delta^{13} \mathrm{C}$ difference suggests that there were drastic changes in primary productivity and/or export productivity to the deep ocean after the K/Pg boundary mass extinction [Zachos and Arthur, 1986; Stott and Kennett, 1989; Zachos et al., 1989; D'Hondt and Zachos, 1998; D'Hondt, 2005; Coxall et al., 2006]. Nonetheless, this interpretation has been called into question by recent studies [Alegret and Thomas, 2009; Alegret et al., 2012] that attribute the collapse to artifacts associated with the dramatic biotic turnover.

Two distinct published hypotheses have been invoked to explain the collapse in surface to deep ocean $\delta^{13} \mathrm{C}$ difference after the $\mathrm{K} / \mathrm{Pg}$ boundary. The Strangelove Ocean hypothesis posits that primary productivity sharply decreased or ceased immediately after the $\mathrm{K} / \mathrm{Pg}$ boundary due to the extinction of primary producers [Broecker and Peng, 1982; Hsu et al., 1982]. The Living Ocean hypothesis postulates that marine primary productivity did not decrease but export productivity (total organic carbon that sank to the deep ocean via the biological pump) was dramatically reduced for a few hundred thousand years and moderately reduced for millions of years [D'Hondt and Zachos, 1998; D'Hondt et al., 1998; D'Hondt, 2005; Coxall et al., 2006]. The Living Ocean hypothesis assumes that total biological productivity recovered rapidly but export productivity from the photic zone was reduced for millions of years because of a greatly altered ecosystem [D'Hondt and Zachos, 1998; D'Hondt, 2005].

In contrast to the Strangelove and Living Ocean hypotheses, Alegret and Thomas [2009] and Alegret et al. [2012] suggested there was little to no decrease in export productivity in wake of the $\mathrm{K} / \mathrm{Pg}$ mass extinction. They noted that export productivity must have persisted at a sufficient level to support phytoplankton-dependent deep-sea benthic foraminifera that did not suffer significant extinctions [Alegret and Thomas, 2009; Alegret et al., 2012]. An increase in the relative abundance of buliminid benthic foraminifera along with a peak in benthic foraminiferal accumulation rates at two Pacific Ocean sites has been interpreted to show high food supply to the sea floor after the K/Pg extinction, in disagreement with both the Strangelove and Living Ocean hypotheses [Alegret and Thomas, 2009; Alegret et al., 2012]. Furthermore, the large $\delta^{13} \mathrm{C}$ decrease in bulk sediment (2-3\%) in open ocean sites and the collapse of the vertical $\delta^{13} \mathrm{C}$ gradient were attributed to the turnover and vital effects in nannofossils and planktonic foraminifera [Alegret et al., 2012]. We term this third ocean model with continued export productivity with little or no reduction in food supply to the sea floor as the Resilient Ocean hypothesis.

Other studies have suggested that postextinction geographic heterogeneity occurred in ecosystem response and export productivity [e.g., Hull and Norris, 2011; Sibert et al., 2014]. Using biogenic barium and other proxies, Hull and Norris [2011] concluded that there was either no change or an increase in export productivity in the central Pacific and in some upwelling or shelf Atlantic sites in the early Paleocene; in contrast, their data in the northeast and southwest Atlantic, Southern Ocean, and Indian Ocean records indicate reduced export productivity. Sibert et al. [2014] similarly found geographic differences in the postextinction ecosystem. They showed that in the Tethys Sea, fish abundance fell abruptly at the K/Pg boundary and remained low for at least three million years, whereas fish abundance in the Pacific Ocean remained at or above preboundary levels for at least four million years following the K/Pg boundary [Sibert et al., 2014]. We term this fourth ocean model as the Heterogeneous Ocean hypothesis, indicating geographic heterogeneity in the extinction patterns and food supply to the sea floor.

Although previous studies have focused on deep-sea sections, we test primary productivity and export productivity changes in a paleoshelf setting that provides important records regarding to the $\delta^{13} \mathrm{C}$ changes across K/Pg boundary. Most organic carbon burial occurs on continental margins [Premuzic et al., 1982], and therefore, any large-scale changes in primary productivity and its export must account for changes recorded on the shelves. Each ocean response has a unique prediction on the shelf in terms of surface waters, deep waters, and water column $\delta^{13} \mathrm{C}$ gradients. The Strangelove Ocean predicts that there would be very limited primary productivity and hence no carbon burial for an extended period. Therefore, in the Strangelove Ocean there would be no $\delta^{13} \mathrm{C}$ gradient on the shelf between surface-dwelling planktonic and benthic foraminifera independent of the depth of the site relative to the photic zone. The Living Ocean, which assumes primary productivity is present, predicts a $\delta^{13} \mathrm{C}$ gradient in the water column among planktonic foraminifera living at different depths. In the Living Ocean, the $\delta^{13} \mathrm{C}$ gradient between surface-dwelling planktonic and benthic foraminifera would vary on the shelf depending on the location, i.e., the depth of the site relative to the photic zone. Shallower shelf sites, where the bottom intersects 


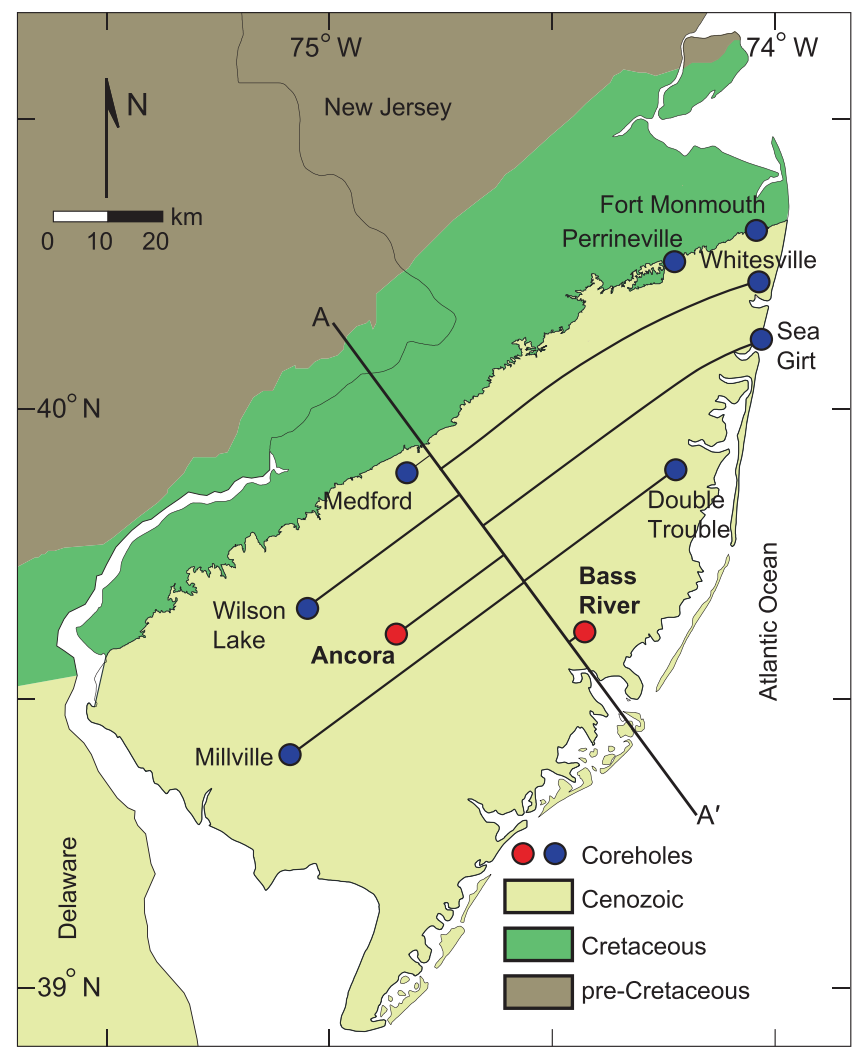

Figure 1. Geological map of New Jersey Coastal Plain with coreholes sampled the K/Pg boundary and drilled by ODP Leg 174AX, ODP Leg $150 \mathrm{X}$, and K/Pg boundary drilling project. Ancora and Bass River coreholes are indicated in red spheres. Structural contours are on the top of the Campanian [Zapecza, 1984]. A-A' is along the dip direction. Figure 2 shows the cross section across $A-A^{\prime}$. the photic zone or the deep layer is shallow, would have higher surface to bottom gradients and lower benthic foraminiferal $\delta^{13} \mathrm{C}$ values than the deeper shelf sites. Therefore, a strong cross-shelf gradient among benthic foraminifera would support the Living Ocean hypothesis. On the other hand, the Resilient Ocean hypothesis predicts little or no change in organic carbon flux across the boundary; hence, surface to bottom and water column gradients would be maintained.

Deep-sea benthic foraminiferal $\delta^{13} \mathrm{C}$ gradients between the Atlantic and Pacific also help to test the hypotheses, because they reflect both water mass differences and global export productivity from the biologic pump [Broecker and Peng, 1982]. If the biologic pump shut down (as predicted by the Strangelove and Living Oceans), then the $\delta^{13} \mathrm{C}$ gradient between the Atlantic and Pacific Oceans would be severely reduced or disappear [Stott and Kennett, 1989; Zachos et al., 1992]. If, however, export productivity remained unchanged across the boundary, then the interbasinal $\delta^{13} \mathrm{C}$ gradient should persist in the absence of a major change in deep water source regions.

Here, we present $\delta^{13} \mathrm{C}$ and $\delta^{18} \mathrm{O}$ records from multiple species of planktonic and benthic foraminifera, $\delta^{13} \mathrm{C}$ changes of bulk and organic carbon, and the changes in the mass accumulation rates of total

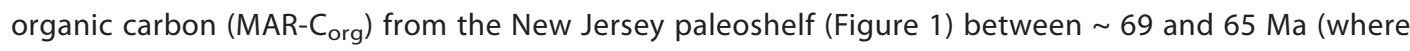
the $\mathrm{K} / \mathrm{Pg}$ boundary is placed at $66.04 \mathrm{Ma}$ ) [Gradstein et al., 2012]. The Ancora (Hole B) and Bass River coreholes drilled by Ocean Drilling Program Leg 174AX [Miller et al., 1998, 1999] provide the most complete $\mathrm{K} / \mathrm{Pg}$ boundary sections in the New Jersey paleoshelf (Figure 2), representing shallower (middle neritic) and deeper shelf environments (middle-outer neritic), respectively. The updip and downdip comparison of the Ancora and Bass River coreholes allows us to distinguish among the different shelf responses because they recorded: (1) mixed layer to thermocline $\delta^{13} \mathrm{C}$ gradients in planktonic foraminifera, (2) cross-shelf $\delta^{13} \mathrm{C}$ gradients in benthic foraminifera, and (3) differences in the rate of organic carbon burial across the $\mathrm{K} / \mathrm{Pg}$ boundary. Our goal is to elucidate the changes in productivity in a paleoshelf setting, evaluate the interbasinal deep-sea $\delta^{13} \mathrm{C}$ differences between Atlantic (ODP Site 1262) and Pacific Oceans (ODP Site 1210), and provide a comparison between shelf and deep-sea record of the $\delta^{13} \mathrm{C}$ changes across the $\mathrm{K} / \mathrm{Pg}$ boundary.

\section{Methods}

For the biostratigraphic analysis and species-specific stable isotope measurements, core samples (20 g) were disaggregated using Calgon solution ( $5.5 \mathrm{~g}$ of sodium metaphosphate per $4 \mathrm{~L}$ of water) and washed with tap water through a $63 \mu \mathrm{m}$ sieve. After drying in an oven at $40^{\circ} \mathrm{C}$, samples were sieved through $250,150,125$, and $63 \mu \mathrm{m}$ sieves and each size fraction examined separately with a reflected-light microscope. Planktonic 


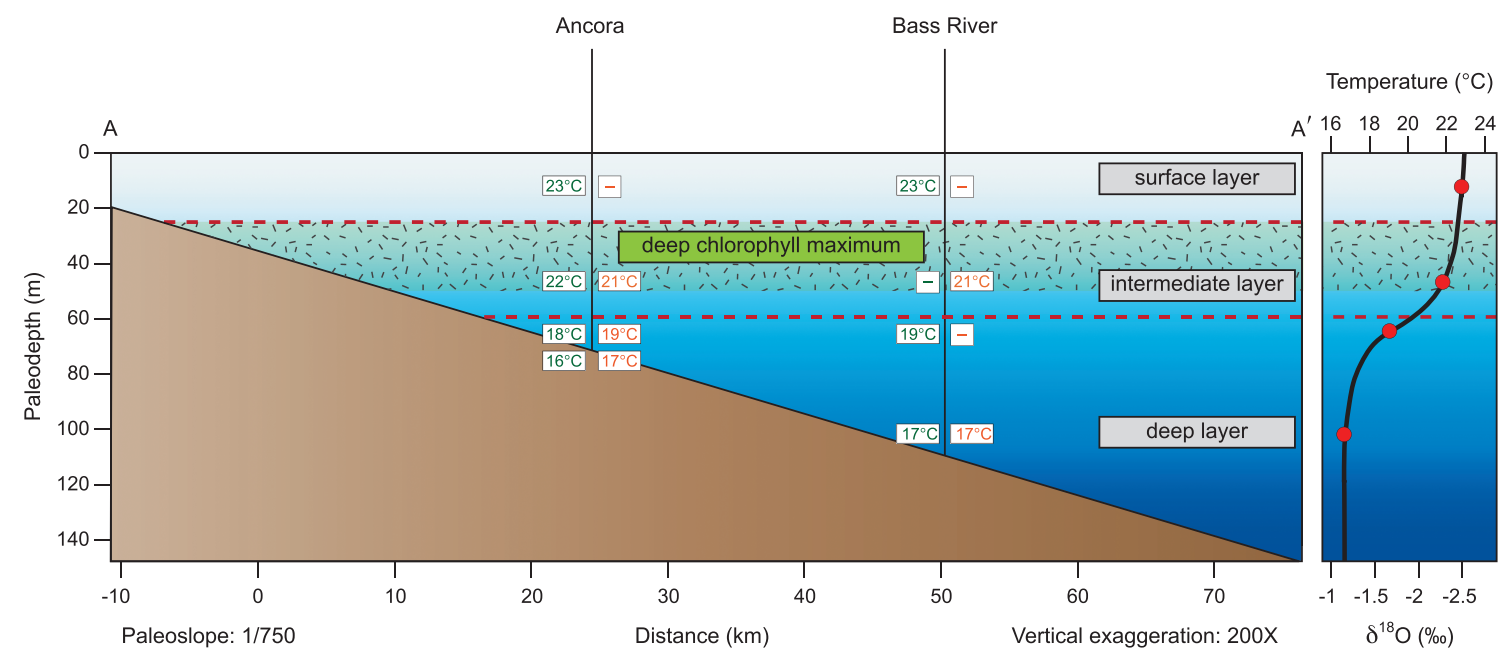

Figure 2. Paleoslope model and paleohydrography of the New Jersey shelf showing locations of Ancora and Bass River. Paleodepths appropriate for the latest Cretaceous to the Danian were estimated assuming a paleoslope of 1:750 (Figure S2 shows the paleowater depths of other New Jersey coreholes indicated in Figure 1. Figures S3 and S4 show reconstructions for paleoslopes of 1:500 and 1:1000, respectively.). Paleotemperature estimates based on $\delta^{18} \mathrm{O}$ of planktonic and benthic foraminifera for different water columns at Ancora and Bass River are indicated (green color for the Maastrichtian and orange color for the Danian). Temperature profile is estimated based on $\delta^{18} \mathrm{O}$ data points indicated in the figure and fitted with a curve similar to modern GEOSECS station 113. The position of the deep chlorophyll maximum is based on modern shelf hydrography [Ryan et al., 1999; Mouw and Yoder, 2005; Glenn et al., 2008].

foraminifera identifications follow the taxonomy of Olsson et al. [1999] for the Danian and Premoli Silva and Verga [2004] for the Maastrichtian.

Stable isotope measurements of foraminifera and bulk carbonate were conducted in the Stable Isotope Laboratory of the Department of Earth and Planetary Sciences at Rutgers University. Samples were loaded into a multiprep device attached to a Micromass Optima mass spectrometer. The $\mathrm{CaCO}_{3}$ was reacted in $100 \%$ phosphoric acid at $90^{\circ} \mathrm{C}$ for $800 \mathrm{~s}$. Values were reported relative to the Vienna Pee Dee Belemnite (VPDB) using internal laboratory reference material that is routinely calibrated against NBS-18 and NBS-19 [Coplen et al., 1983]. The long-term standard deviation on the internal laboratory standard is $0.05 \%$ and $0.08 \%$ for $\delta^{13} \mathrm{C}$ and $\delta^{18} \mathrm{O}$ measurements, respectively.

Bulk samples collected from Ancora and Bass River were dried at $40^{\circ} \mathrm{C}$ and homogenized using a ceramic mortar and pestle. Isotopic ratios for organic carbon and TOC were measured at the Boone Pickens School of Geology at the Oklahoma State University using a Thermo Finnigan Delta Plus XL isotope ratio mass spectrometer interfaced to a Costech ECS 4010 elemental analyzer (EA). Organic carbon isotope and concentration measurements were performed on 10-20 mg of sample, which was placed in silver capsules and decarbonated using hydrochloric acid, oven dried at $40^{\circ} \mathrm{C}$, and then wrapped in tin capsules. Carbon isotope delta values $\left(\delta^{13} \mathrm{C}_{\text {org }}\right)$ for Bass River are reported relative to VPDB and calculated using two isotopic standards, USGS40 and USGS24, whose values were calibrated using the L-SVEC/NBS-19 scale [Coplen et al., 2006]. Replicates for carbon standards had a standard deviation of $\pm 0.1 \%$. Replicates of Bass River sediment samples for $\delta^{13} C_{\text {org }}$ had a standard deviation of less than $\pm 0.2 \%$. TOC was calculated from the EA chromatogram using an acetanilide standard curve; replicates of samples had a standard deviation of $\pm 0.03 \mathrm{wt} \%$ for Bass River and $\pm 0.07 \%$ for Ancora. Additional TOC measurements were conducted for Ancora samples at Rutgers University with Carlo Erba NA1500 series $2 \mathrm{EA}$ with a similar analytical procedure.

Measurements for total nitrogen (TN) for both Ancora and Bass River samples were performed on a Eurovector EA attached under continuous flow to a GV Instruments IsoPrime isotope ratio mass spectrometer in the Stable Isotope Laboratory of the Department of Earth and Planetary Sciences at Rutgers University, using procedures described previously in Quan et al. [2008]. Samples for nitrogen measurements were performed on bulk sediment, and vanadium pentoxide was added as a catalyst. TN was calculated from the EA chromatogram using an acetanilide standard curve; replicate analyses of the nitrogen samples had a variation in TN of $<0.1 \%$. 


\section{Results}

3.1. New Jersey Paleoshelf

3.1.1. Biostratigraphy and Age Calibration

Upper Cretaceous to lower Paleocene strata at Ancora and Bass River consist of glauconitic clay and clayey glauconitic sand deposited in neritic paleoenvironments. Bass River provides a continuous record of deposition across the K/Pg boundary with preservation of impact spherules and a reworked Cretaceous clast layer [Olsson et al., 1997]. Ancora lacks the spherule layer at the K/Pg boundary, though reworked clay clasts containing spherules occur immediately above the boundary [Miller et al., 1999].

The age model was constructed using planktonic foraminiferal datum events based on the chronology of Huber et al. [2008] for the Cretaceous and Olsson et al. [1999] and Berggren and Pearson [2005] for the Paleocene. Ages are calibrated to Geological Time Scale (GTS) 2012 [Gradstein et al., 2012] (Figure S1 and Tables S1 and S2 in the supporting information show planktonic foraminiferal datum events used for the age calibration and the age-depth data tables for Ancora and Bass River).

At Ancora, the interval $198.42 \mathrm{~m}$ below land surface (mbls) to $194.22 \mathrm{mbls}$ is defined as the Abathomphalus mayaroensis Zone equivalent with the Highest Occurrence (HO) of Globotruncana linneiana at 196.90 mbls (Figure 3). The taxon Abathomphalus mayaroensis is absent probably due to ecologic exclusion in paleowater depths < $200 \mathrm{~m}$. The interval between $194.22 \mathrm{mbls}$ and $188.49 \mathrm{mbls}$ was defined as the Pseudoguembelina hariaensis/Plummerita hantkeninoides Zone (Figure 3). The absence of Abathomphalus mayaroensis did not allow us to differentiate between the Pg. hariaensis and PI. hantkeninoides Zones. For Ancora, we used two datum events in the Maastrichtian, the HO of Globotruncana linneiana (68.37 Ma) and the HO of G. gansseri (66.49 Ma) (Figures 3 and S1 and Table S1). The base of Zone P0 (66.04 Ma) was determined by the extinction level of Cretaceous planktonic foraminiferal taxa, and the base of Zone P $\alpha$ was determined by the Lowest Occurrence (LO) of Parvularugoglobigerina eugubina (66.00 Ma). Previous studies indicated a hiatus between Zone P $\alpha$ and Zone P1a [Miller et al., 1999]. At 188.09 mbls within Zone $\mathrm{P} 1 \mathrm{a}$, a $2.6 \mathrm{~cm}$ thick layer of spherules (microtektites), grains of glauconite, intermixed clay, and foraminifera was observed [Miller et al., 1999]. The presence of glauconite grains and foraminifera in this layer was interpreted as an indication of the redeposition of the original microtektites and a short hiatus between Zones P $\alpha$ and P1a [Miller et al., 1999]. The interval from $188.14 \mathrm{mbls}$ to $186.84 \mathrm{mbls}$ is assigned to Zone P1a (Figure 3) and contains Eoglobigerina edita, Globoconusa daubjergensis, Guembelitria cretacea, Parasubbotina pseudobulloides, and Praemurica taurica. The base of Zone P1b was determined by the LO of Subbotina triloculinoides (65.25 Ma); in this zone E. edita, Gc. daubjergensis, Pa. pseudobulloides, Pr. taurica, and S. triloculinoides were identified. The ages of samples between each datum event were interpolated assuming a constant sedimentation rate (Figure S1). Because of the hiatus reported in Miller et al. [1999] between Zone $\mathrm{P} \alpha$ and Zone P1a, we extrapolated the age of the first sample of Zone P1a using the sedimentation rate of Zone $\mathrm{P} \alpha$ assuming constant sedimentation rate and calculated the hiatus as $0.23 \mathrm{Ma}$.

For Bass River, the interval between 391.06 mbls to 384.12 mbls was defined as the Pg. hariaensis/PI. hantkeninoides Zone (Figure 3). In the Pg. hariaensis/PI. hantkeninoides Zone, we used two datum events for age calibration, the LO of Pg. hariaensis (67.30 Ma) and the HO of Gansserina gansseri (66.49 Ma). Zone $\mathrm{PO}$ is defined as the interval between the extinction of Cretaceous planktonic foraminiferal taxa (66.04 Ma) and the LO of $P$. eugubina (66.00 Ma) (Figure S1 and Table S2). Zone P0 at Bass River includes a $6 \mathrm{~cm}$ thick spherule (altered microtektite) layer with common shocked quartz grains and carbonate accretionary lapilli resulting from fallout of ballistic ejecta from the Chicxulub Crater in Yucatan, Mexico [Olsson et al., 1997; Miller et al., 1998, 2010]. The LO of P. eugubina marks the base of Zone P $\alpha(66.00 \mathrm{Ma})$, and the HO of the same taxon marks the base of Zone P1a (65.72 Ma). Planktonic foraminifera species that occur in Zone P $\alpha$ and P1a include Eoglobigerina eobulloides, E. edita, Pa. pseudobulloides, Pr. taurica, S. trivialis, Woodringina claytonensis, and Woodringina hornerstownensis. The ages of samples between each datum event were interpolated assuming a constant sedimentation rate (Figure S1). The ages of the samples above the base of Zone P1a (interval 383.97 mbls to 383.87 mbls) were extrapolated using the sedimentation rate of Zone $\mathrm{P} \alpha$. There is an unconformity at $383.8 \mathrm{~m}$ separating Zone P1a from Zone P1c [Miller et al., 1998].

\subsubsection{Paleowater Depth Estimates}

Paleowater depth estimates were made by projecting the sites to a dip profile (A-A'; Figure 1$)$ from the outcrop adjacent to Medford, NJ, through the Bass River corehole using structural contours on top of the 


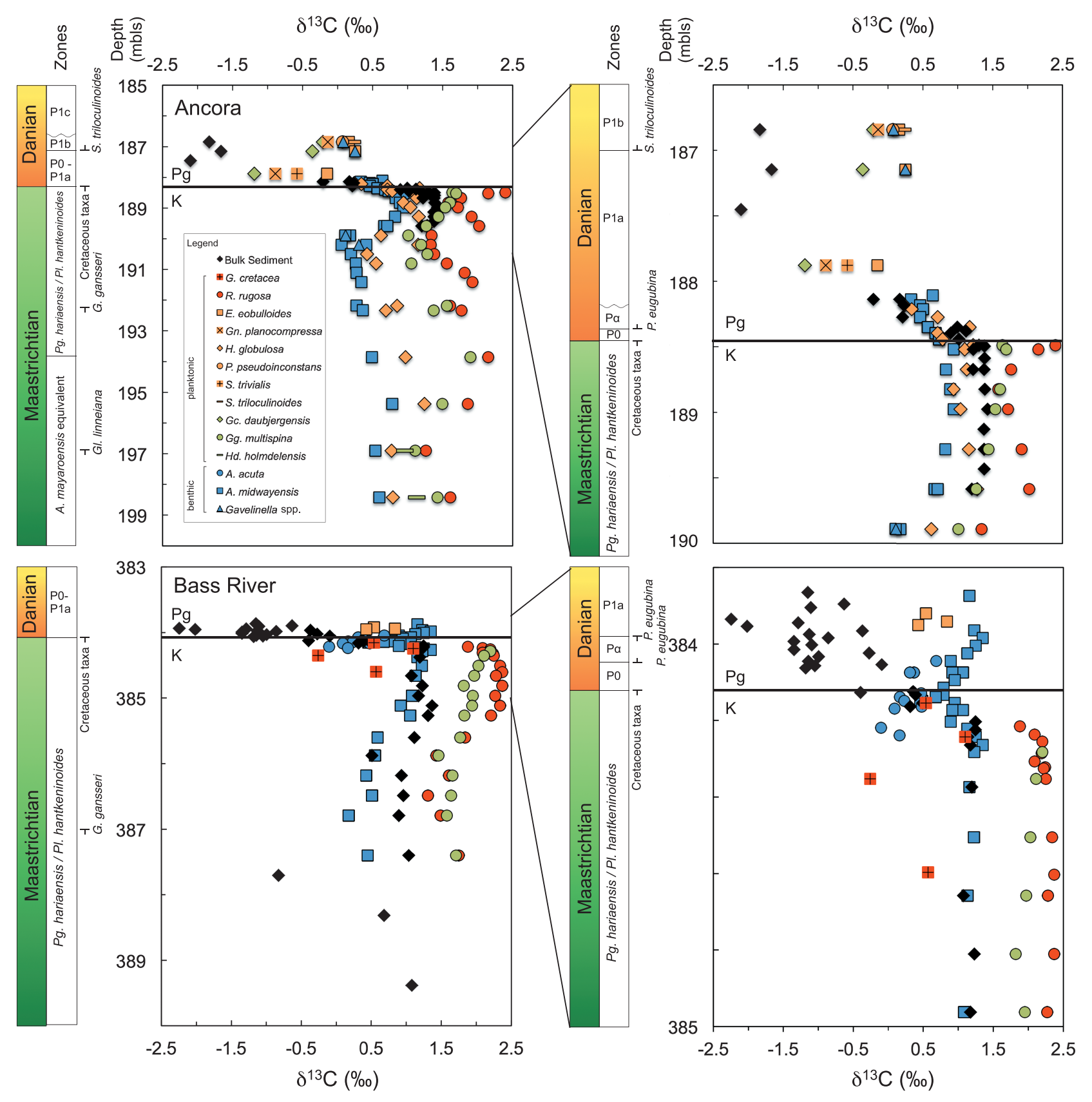

Figure 3. $\delta^{13} \mathrm{C}$ changes versus depth across the $\mathrm{K} / \mathrm{Pg}$ boundary at the Ancora and Bass River coreholes. Right panels zoom into the $\mathrm{K} / \mathrm{Pg}$ boundary transition and show details of Danian biozones. Lowest $(\perp)$ and highest $(T)$ occurrences of planktonic foraminifera used in biozone determination and age calibration are shown. mbls: meter below land surface. Black: bulk sediments, red: surface-dwelling planktonic foraminifera, orange: intermediate-dwelling planktonic foraminifera, green: deep-dwelling planktonic foraminifera, and blue: benthic foraminifera. Legend indicates species key.

Campanian Mount Laurel Formation (Figure 1) [Zapecza, 1984]. Previous paleobathymetric studies in New Jersey have assumed Cretaceous to Eocene paleoslope gradients similar to the modern 1:1000 shelf gradients [Olsson and Nyong, 1984; Browning et al., 1997; Harris et al., 2010]. 2-D backstripping of Steckler et al. [1999] allows modeling of paleogradients by accounting for the effects of compaction, loading and thermal subsidence. The oldest surface backstripped by Steckler et al. [1999] on the New Jersey margin was the 01 sequence boundary (lower Oligocene) [Browning et al., 2013], which yielded gradients beneath the coastal plain of 1:1000 to 1:500, with a best fit of 1:800 [Steckler et al., 1999, Figure 6a). Kominz and Pekar [2001] used 1:500 as the gradient for the Paleogene ramp profile on which succeeding Oligocene-Miocene 
clinoforms were built. The precise geometry of the Cretaceous paleoslope is not certain, with best estimates of $\sim 1: 750$ (M. Steckler, written communication, 2014). Therefore, we used 1:750 in this study (Figures 2 and S2) and also provided reconstructions for 1:500 and 1:1000 (Figures S3 and S4). The minimum water depths and thus the paleodepth projections are anchored by the Perrineville, Campo Pit outcrop deposited in a lower shoreface paleoenvironment below storm wave base with paleodepths of $25 \pm 5 \mathrm{~m}$ [Esmeray-Senlet et al., 2015]. There is uncertainty of $\pm 5 \mathrm{~m}$ in the relative placement of the coreholes; given the different end-member gradients. The errors in the absolute paleodepths are up to $\pm 20 \mathrm{~m}$ (Figure S2 provides paleowater depth estimates of all coreholes and outcrops on Figure 1.). Both Bass River (paleodepth of $\sim 110$ $\pm 20 \mathrm{~m}$ ) and Ancora (paleodepth of $70 \pm 10 \mathrm{~m}$ ) were located on the middle-outer shelf during the Late Cretaceous-early Paleogene transition (Figure 2).

\subsubsection{Paleohydrographic Reconstructions}

Modern shelf hydrography provides insights into continental shelf processes that are applicable to the K/Pg paleoshelf. The deep chlorophyll maximum (DCM) occurs on the shelf in the lower photic zone (25-50 m) due to the balance of irradiance and nutrient supply from the deeper shelf. In the spring to summer, the water column becomes stratified with the shelf thermocline forming a boundary between nutrient-depleted surface mixed layer above and the nutrient-rich deep layer below [Pingree et al., 1976; Fairbanks and Wiebe, 1980; Cullen, 1982; Hickman et al., 2009]. During this seasonal stratification, the DCM is typically located at the base of the surface mixed layer within the shelf thermocline and is strongly coupled to the nutricline [Cullen, 1982; Sharples et al., 2001; Hickman et al., 2009]. On the modern western North Atlantic shelf, primary productivity is strongly concentrated in the stratified months [Ryan et al., 1999; Mouw and Yoder, 2005; Glenn et al., 2008]. The thermocline and the DCM break down in the fall to winter under the influence of storms [Glenn et al., 2008]. The deep layer (>60-100 m; paleodepth of Ancora and Bass River) remains unmixed except during the most severe storms and remains essentially isothermal annually [Glenn et al., 2008]. In a warmer world such as the Late Cretaceous-Paleogene greenhouse [Olsson et al., 2001], winds that drive the breakdown of the seasonal thermocline in this region would have been potentially weaker and stratification more pronounced [Hay and Floegel, 2012], and the DCM presumably stronger and perhaps a year-long feature. Paleolatitudes of this region were similar to today $\left(\sim 40^{\circ} \mathrm{N}\right)$ [Müller et al., 2008] to lower ( $\left.28^{\circ} \mathrm{N}\right)$ [Kopp et al., 2009]. Considering all these factors, we estimate the depth of the DCM as between 25 and $50 \mathrm{~m}$ for the New Jersey paleoshelf for the latest Cretaceous to the Danian during the spring to summer bloom (Figure 2), when most productivity occurs.

\subsubsection{Stable Isotope Results}

At Ancora and Bass River, we measured $\delta^{13} \mathrm{C}$ of bulk and organic carbon, and $\delta^{13} \mathrm{C}$ and $\delta^{18} \mathrm{O}$ of monospecific planktonic and benthic foraminifera from several species and genera (Figures 3-5; see Data Sets S1 and S2 in the supporting information for isotope data). We measured planktonic foraminiferal taxa Rugoglobigerina rugosa, Globigerinelloides multispina, Heterohelix globulosa, Hedbergella holmdelensis, and Guembelitria cretacea for the Maastrichtian, and Eoglobigerina eobulloides, Subbotina trivialis, Subbotina triloculinoides, Globanomalina planocompressa, Praemurica pseudoinconstans, and Globoconusa daubjergensis for the Danian. We analyzed the benthic foraminiferal taxa Anomalinoides midwayensis, Anomalinoides acuta, and Gavelinella spp. across the boundary, all of which survived the K/Pg extinction.

Previous studies showed a positive correlation between test size and $\delta^{13} \mathrm{C}$ values in small (typically $<150 \mu \mathrm{m}$ ) early Danian planktonic foraminifera [D'Hondt and Zachos, 1993; Norris, 1996; Birch et al., 2012]. Therefore, we estimated vital effects in our species-specific planktonic foraminiferal $\delta^{13} \mathrm{C}$ measurements for postextinction taxa and for the species G. cretacea in the latest Maastrichtian (supporting information Table S3). Using size specific $\delta^{13} \mathrm{C}$ measurements of planktonic foraminifera from ODP Site 1262 [Birch et al., 2012] and DSDP Site 528 [D'Hondt and Zachos, 1993] and taking $150 \mu \mathrm{m}$ as a cutoff for size related metabolic overprint [Birch et al., 2012], we calculated the amount of vital effect varying between 0 and $0.4 \%$ o (Table S1). Our estimates are in agreement with Bornemann and Norris [2007], who showed that metabolic effects could cause 0.3 to $0.5 \%$ o depletion of planktonic foraminiferal calcite equilibrium $\delta^{13} \mathrm{C}$ values. We interpreted our results using the vital effect corrected $\delta^{13} \mathrm{C}$ values (Figures 3, 4, and 6), accounting for the metabolic effects of small taxa, even though the estimated vital effects are too small to change the interpretations of $\delta^{13} \mathrm{C}$ gradient of DIC in the early Danian.

3.1.4.1. Paleoecology of Planktonic Foraminifera

We determined the depth habitats of the planktonic foraminifera and characterized them as surface, intermediate, and deep layer dwellers using $\delta^{18} \mathrm{O}$ rankings (Figure 5). The $\delta^{18} \mathrm{O}$ of calcite is dependent on 


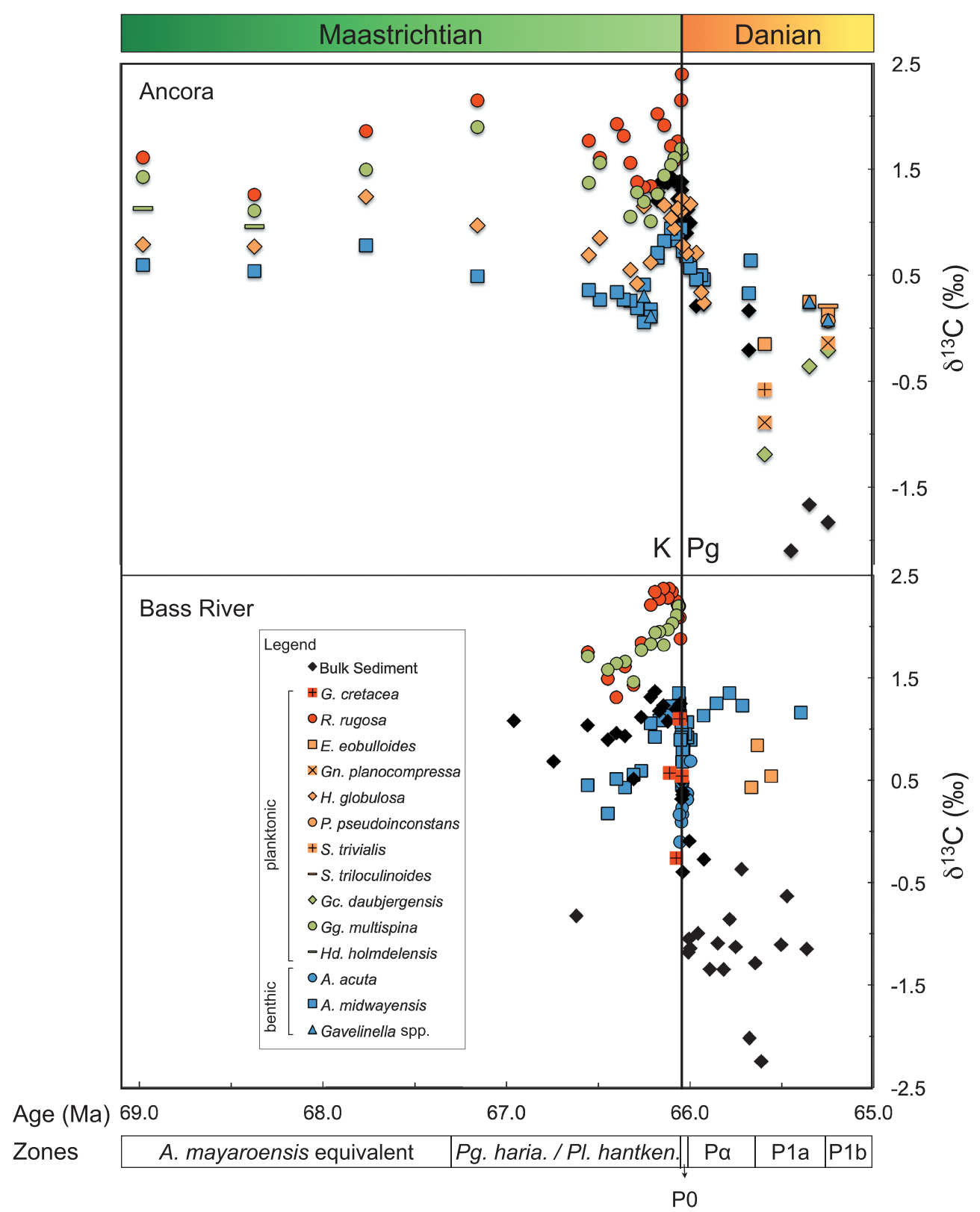

Figure 4. $\delta^{13} \mathrm{C}$ changes across the $\mathrm{K} / \mathrm{Pg}$ boundary at the Ancora and Bass River coreholes. Ages are based on planktonic foraminiferal biozones calibrated to GTS-2012 [Gradstein et al., 2012]. $\delta^{13} \mathrm{C}$ values of G. cretacea and Danian planktonic foraminifera species except Gn. planocompressa are vital effect corrected (supporting information Table S3). Black: bulk sediments, red: surface-dwelling planktonic foraminifera, orange: intermediate-dwelling planktonic foraminifera, green: deep-dwelling planktonic foraminifera, and blue: benthic foraminifera. Legend indicates species key.

the temperature of the water from which it is precipitated [Emiliani, 1954] and therefore provides constraints on depth habitats of extinct planktonic foraminifera [e.g., D'Hondt and Zachos, 1993; Pearson et al., 2001; Wade and Pearson, 2008].

Guembelitria cretacea, one of the survivor species with $\mathrm{Hd}$. holmdelensis and $\mathrm{Hd}$. monmouthensis [Olsson and Liu, 1993; Olsson et al., 1999], has the lowest $\delta^{18} \mathrm{O}$ values (Figures 5 and 6 ) indicating its preference to live in surface waters, as also shown in previous studies [D'Hondt and Zachos, 1993; Koutsoukos, 1996]. The Maastrichtian planktonic taxon $R$. rugosa has also low $\delta^{18} \mathrm{O}$ values, and it is considered as a surface dweller (Figure 5) in agreement with previous studies [Boersma and Shackleton, 1981]. H. globulosa has higher $\delta^{18} \mathrm{O}$ 


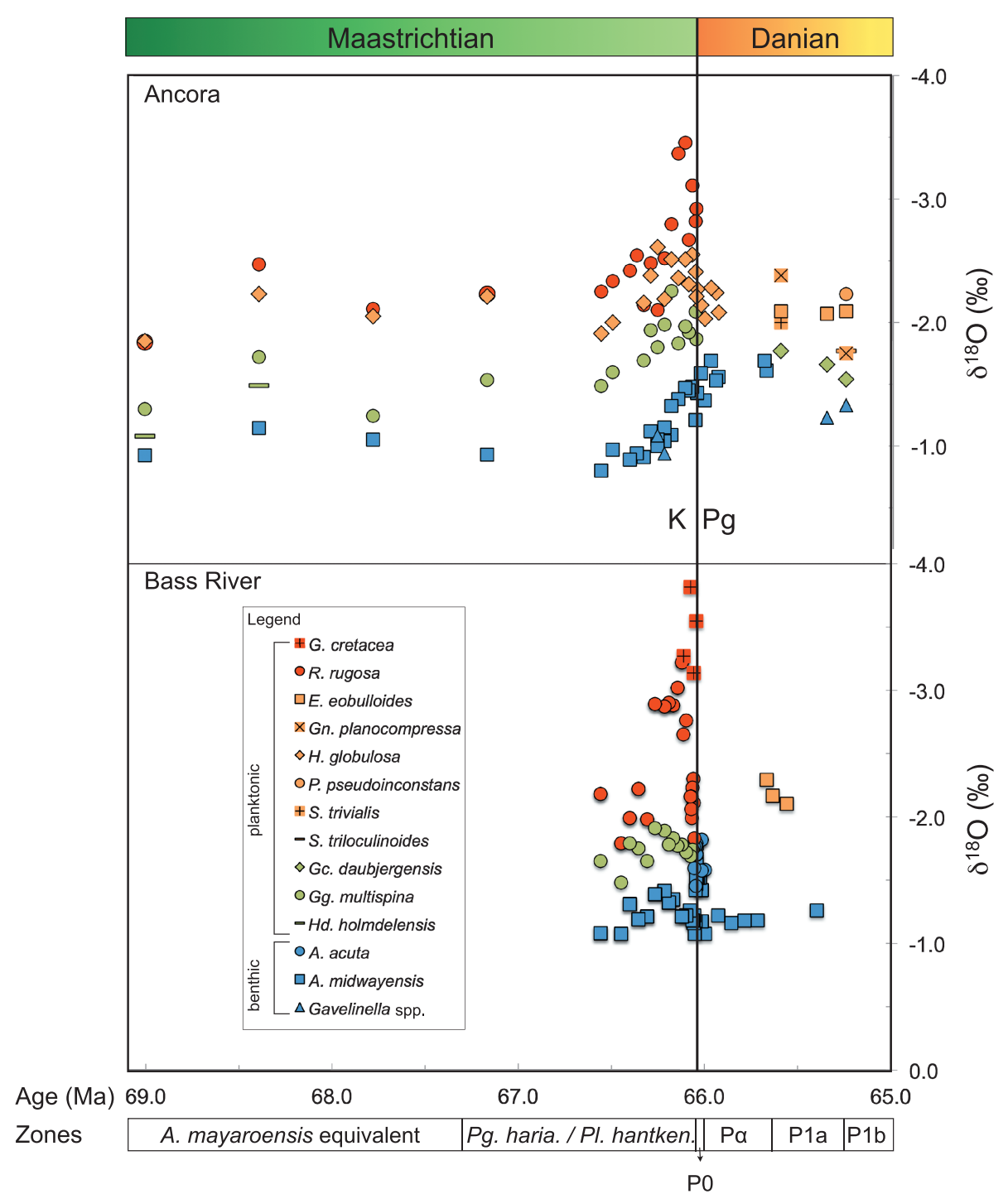

Figure 5. $\delta^{18} \mathrm{O}$ changes across the K/Pg boundary at the Ancora and Bass River coreholes. Ages are based on planktonic foraminiferal biozones calibrated to GTS-2012 [Gradstein et al., 2012]. Red: surface-dwelling planktonic foraminifera, orange: intermediate-dwelling planktonic foraminifera, green: deep-dwelling planktonic foraminifera, and blue: benthic foraminifera. Legend indicates species key.

values than $R$. rugosa and is considered an intermediate dweller, and Gg. multispina and $\mathrm{Hd}$. holmdelensis are identified as deep dwellers based on the highest $\delta^{18} \mathrm{O}$ values (Figure 5).

In the Danian, the newly evolved planktonic foraminifera species E. eobulloides, S. trivialis, S. triloculinoides, Pr. pseudoinconstans, and Gn. planocompressa are considered intermediate dwellers based on their $\delta^{18} \mathrm{O}$ values (Figure 5). Subbotina species were also considered cool temperature, intermediate depth species in previous studies [Norris, 1996; Birch et al., 2012]. Globoconusa daubjergensis, which evolved from the Cretaceous survivor G. cretacea [Olsson et al., 1999], shows higher $\delta^{18} \mathrm{O}$ values than other Danian planktonic foraminifera indicating a preference for cooler water (Figure 5).

There is also a relationship between $\delta^{18} \mathrm{O}$ and $\delta^{13} \mathrm{C}$ values [Pearson et al., 2001; Wade and Pearson, 2008]. Surface dwellers typically have the highest $\delta^{13} \mathrm{C}$ due to photosynthesis in the photic zone, whereas intermediate and deep dwellers have lower $\delta^{13} \mathrm{C}$ values due to export and oxidative regeneration of organic carbon (Figure 6). The relationship between $\delta^{18} \mathrm{O}$ and $\delta^{13} \mathrm{C}$ is well expressed in the Maastrichtian, with an exception of the taxa, Gg. multispina (Figure 6). We attribute the higher $\delta^{13} \mathrm{C}$ values of deep 

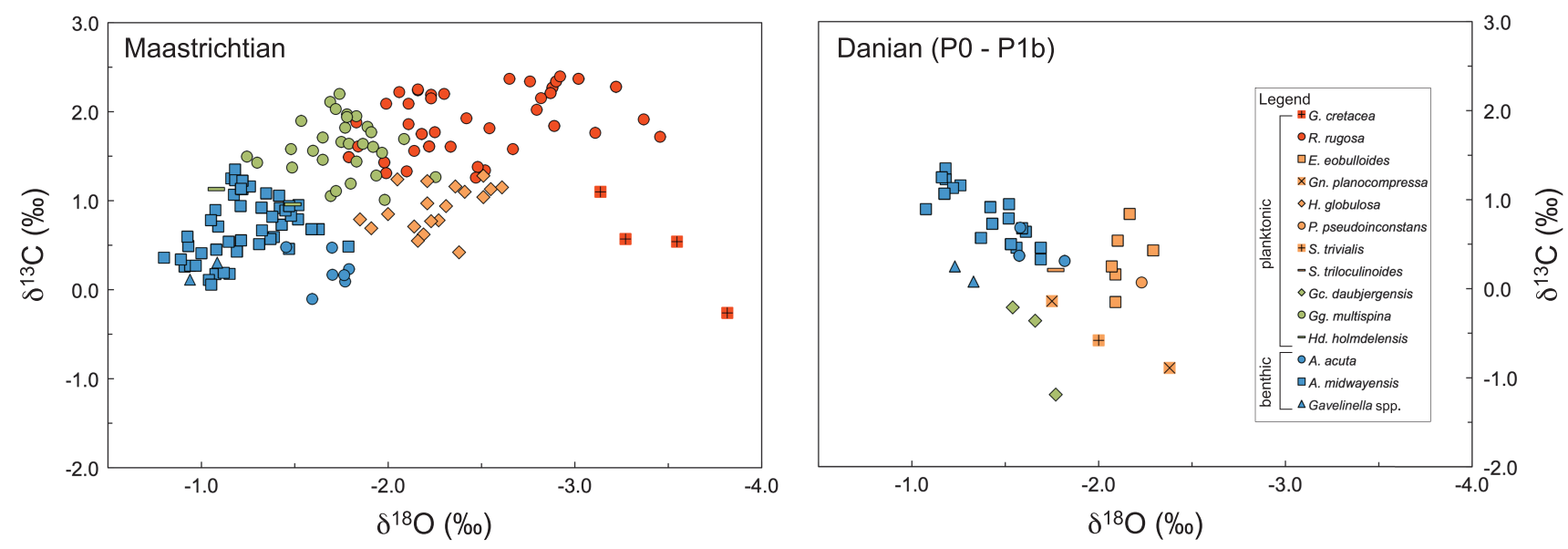

Figure 6. $\delta^{13} \mathrm{C}$ versus $\delta^{18} \mathrm{O}$ values of planktonic and benthic foraminifera in the Maastrichtian and early Danian (Zones P0-P1b) from Ancora and Bass River coreholes. $\delta^{13} \mathrm{C}$ values of G. cretacea and Danian planktonic foraminifera species except Gn. planocompressa are vital effect corrected (supporting information Table S3). Red: surfacedwelling planktonic foraminifera, orange: intermediate-dwelling planktonic foraminifera, green: deep-dwelling planktonic foraminifera, and blue: benthic foraminifera.

dweller Gg. multispina and $\mathrm{H}$. holmdelensis than those of intermediate dweller $\mathrm{H}$. globulosa due to changes in the surface mixed layer related to seasonal differences. The relationship of $\delta^{13} \mathrm{C}$ and $\delta^{18} \mathrm{O}$ values in the Danian is completely the opposite (Figure 6). In other words, the vertical gradients reversed in the early Danian, such that newly evolved planktonic foraminifera recorded lower $\delta^{13} \mathrm{C}$ values than benthic foraminifera (Figures 4 and 6).

In the early Danian, planktonic foraminifera occupied a much narrower range of the water column than they did in the Maastrichtian (Figures 4 and 6). The newly evolved planktonic foraminifera record minimum $\delta^{18} \mathrm{O}$ values that are $\sim 1 \%$ o higher than the minimum Maastrichtian species (Figures 5 and 6 ). This suggests that either surface waters were $4-5^{\circ} \mathrm{C}$ cooler [Shackleton, 1974] or that the early Danian (P0-P1b) planktonic foraminifera did not occupy the surface layer (Figures 5 and 6). The taxa with the lowest $\delta^{18} \mathrm{O}$ values also have the lowest $\delta^{13} \mathrm{C}$ values, indicating calcification in the DCM. This implies that the survivor and newly evolved taxa were grazers living within the DCM and that symbiosis associated with surface dwellers was eliminated in the extinction event, in agreement with previous studies [Norris, 1996; Birch et al., 2012]. The absence of planktonic foraminiferal calcification in surface waters means that $\delta^{18} \mathrm{O}$ values provide no information on surface layer temperature changes.

\subsubsection{Paleotemperature Estimates}

We estimated paleotemperature of the water column using $\delta^{18} \mathrm{O}$ values of benthic foraminifera and planktonic foraminifera living at different depths. Several paleotemperature equations have been developed to show the relation of oxygen isotopes with temperature and continental ice volume based on the original temperature equation proposed by Epstein et al. [1953]. We used the below paleotemperature equation of Shackleton [1974], which is based on $O^{\prime} N e i l$ [1969], where " $\delta^{18} \mathrm{O}_{c}$ " stands for $\delta^{18} \mathrm{O}$ of the carbonate and " $\delta^{18} \mathrm{O}_{\mathrm{w}}$ " for the $\delta^{18} \mathrm{O}$ of seawater.

$$
T=16.9-4.38 *\left(\delta^{18} \mathrm{O}_{\mathrm{c}}-\delta^{18} \mathrm{O}_{\mathrm{w}}\right)+0.10 *\left(\delta^{18} \mathrm{O}_{\mathrm{c}}-\delta^{18} \mathrm{O}_{\mathrm{w}}\right)^{2}
$$

Today, the overall average isotopic composition of ocean water, in terms of VPDB is about $-0.28 \%$ [Craig, 1965]. Considering the ice-volume component to the $\delta^{18} \mathrm{O}$ as 0.8 to $1 \%$ [Shackleton and Kennett, 1975], we used the $\delta^{18} \mathrm{O}_{\mathrm{w}}$ as $-1.2 \%$ o for an ice-free world during the $\mathrm{K} / \mathrm{Pg}$ boundary transition. More recent calibrations [Kim and O'Neil, 1997; Bemis and Spero, 1998] yielded slightly lower values, but the relative differences between the surface and deep waters are essentially the same. Enrichments due to evaporation in subtropics would cause higher $\delta^{18} \mathrm{O}_{\text {wi }}$ therefore, our estimates indicate minimum paleotemperatures.

Paleotemperature estimates show that late Maastrichtian surface-water temperatures were $\sim 23^{\circ} \mathrm{C}$, shelf thermocline temperatures were $\sim 21-22^{\circ} \mathrm{C}$, deep-shelf temperatures were $\sim 18-19^{\circ} \mathrm{C}$, and the shelf bottom water temperatures were $\sim 16-17^{\circ} \mathrm{C}$ (Figure 2). The surface to bottom paleotemperature gradient $\left(\sim 7^{\circ} \mathrm{C}\right.$ ) was about the half of the present day's gradient [Glenn et al., 2008] consistent with a lower meridional thermal gradient and slower ocean circulation [Hay and Floegel, 2012]. Danian paleotemperature estimates 


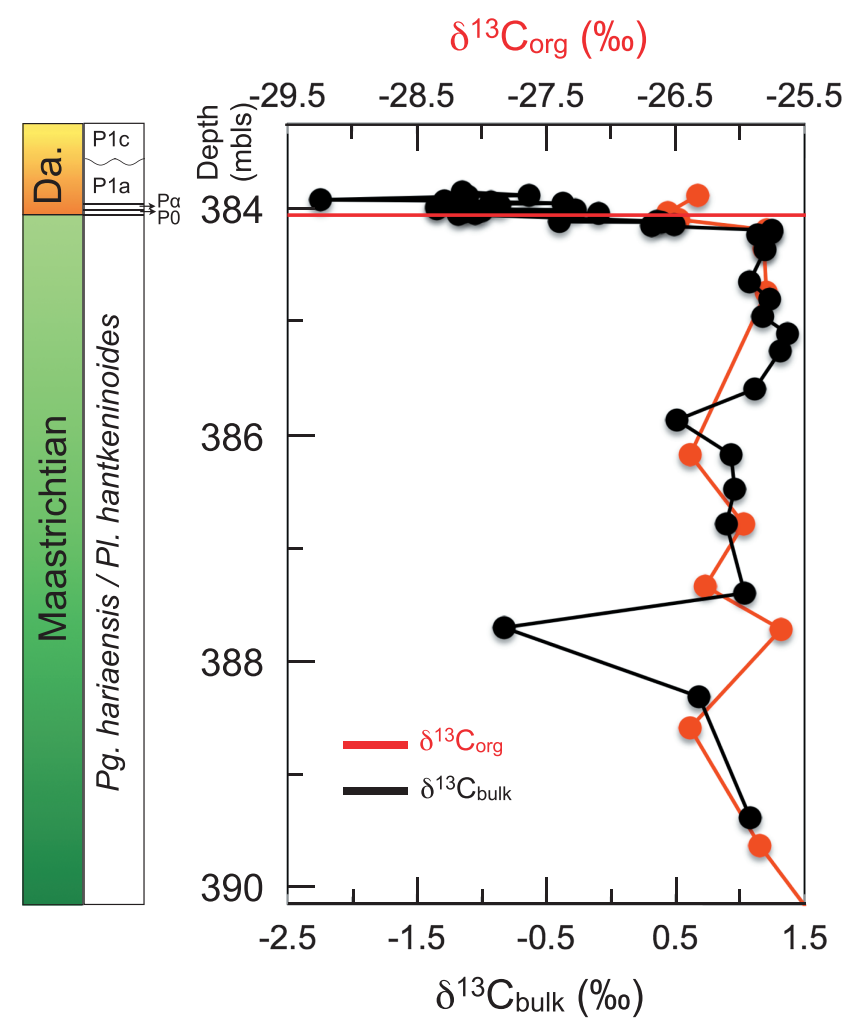

Figure 7. $\delta^{13} \mathrm{C}$ values of organic $\left(\delta^{13} \mathrm{C}_{\mathrm{org}}\right)$ and bulk $\left(\delta^{13} \mathrm{C}_{\text {bulk }}\right)$ at Bass River. Note the planktonic foraminiferal biozones and the unconformity between Biozones P1a and P1c.

$\delta^{13} \mathrm{C}$ gradient within the water column, resembling modern shelf environments [K (3) gradient within the water column, resembling modern shelf environments [Kroopnick, 1985]. Across the boundary, planktonic foraminiferal $\delta^{13} \mathrm{C}$ values decreased by $\sim 2 \%$ at both Ancora and Bass River. Benthic foraminiferal $\delta^{13} \mathrm{C}$ values at both Bass River and Ancora show a gradual increase in the late Maastrichtian toward the $\mathrm{K} / \mathrm{Pg}$ boundary and a sharp decrease at the boundary. At Bass River a $\sim 1 \%$ decrease of benthic foraminiferal $\delta^{13} \mathrm{C}$ values is followed by a $\sim 0.5 \%$ increase across the boundary. Ancora shows a $\sim 0.5 \%$ drop across the boundary, and the decreasing trend continues in the early Danian (Figures 3, 4, and 8). The vertical $\delta^{13} \mathrm{C}$ gradient between planktonic and benthic foraminifera collapsed across the boundary at both sites and the fully developed water column structure of planktonic foraminifera exhibited by $\delta^{13} \mathrm{C}$ gradients was also lost (Figures 3 and 4).

\subsubsection{Total Organic Carbon and Nitrogen}

We measured the total organic carbon (TOC) across the $\mathrm{K} / \mathrm{Pg}$ boundary at Ancora and calculated mass accumulation rates of TOC (MAR- Crg $_{\text {) }}$ (Figures 8 and S5; also see Data Sets S1 and S2 in the supporting information for TOC values) in order to evaluate changes in export productivity independent of isotopic tracers using the following formula:

$$
\text { MAR- } C_{\text {org }}=\text { TOC }(\text { percentage }) * \text { density * sedimentation rate }
$$

Bulk density of the samples was measured, and sedimentation rates were calculated using planktonic foraminiferal events and GTS-2012 ages [Gradstein et al., 2012]. MAR-C $C_{\text {org }}$ shows a large decrease of $\sim 0.7 \mathrm{~g} / \mathrm{cm}^{2} / \mathrm{kyr}$ across the boundary and with very low accumulation of organic carbon $\left(\sim 0.2 \mathrm{~g} / \mathrm{cm}^{2} / \mathrm{kyr}\right)$ in the early Danian (Figure 8).

In order to verify that bulk organic carbon is marine, we measured total nitrogen (TN) percentages of the samples from Ancora and Bass River and analyzed carbon to nitrogen (C/N) ratios of the samples (Figure S6 and Data Sets S1 and S2). Ancora and Bass River show C/N ratios that average 10 and 14, respectively, in the early Danian and both indicate a marine source [Sampei and Matsumoto, 2001; Ohkouchi et al., 2003]. Furthermore, the relationship of $\mathrm{C} / \mathrm{N}$ ratio to average $\delta^{13} \mathrm{C}_{\text {org }}(-26.5 \%$ o) in the early Danian (Figure 7) 


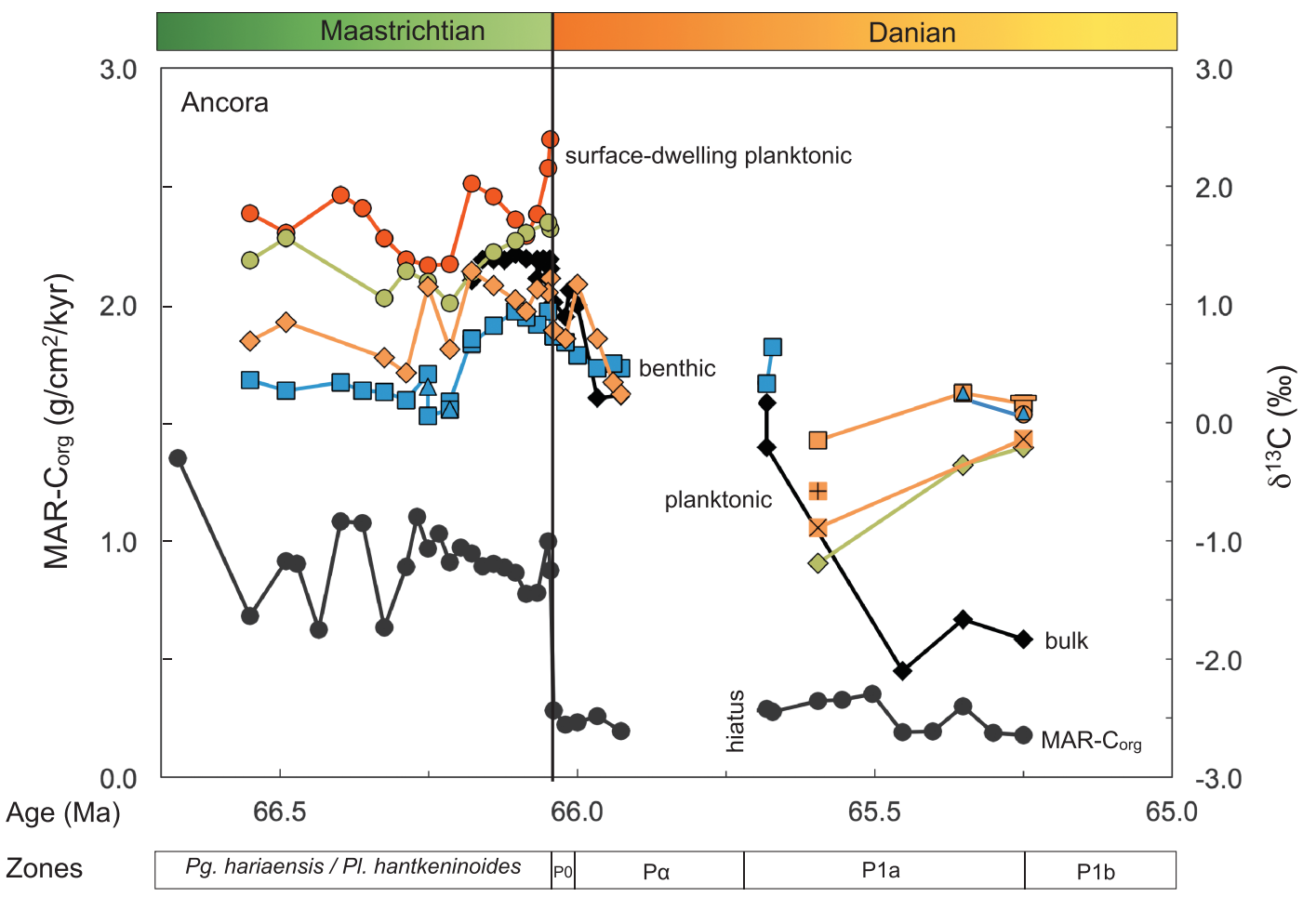

Figure 8. $\delta^{13} \mathrm{C}$ and MAR- $C_{\text {org }}$ values at the Ancora corehole between 65.25 and $66.50 \mathrm{Ma}$. Black circles represent MAR- $\mathrm{C}_{\text {org }}$ values. Danian planktonic foraminiferal $\delta^{13} \mathrm{C}$ values are vital effect corrected except the species Gn. planocompressa (supporting information Table S3). For the $\delta^{13} \mathrm{C}$ values: black diamonds: bulk sediments, red: surface-dwelling planktonic foraminifera, orange: intermediate-dwelling planktonic foraminifera, green: deep-dwelling planktonic foraminifera, and blue: benthic foraminifera. See legend in Figure 5 for species key.

indicates that the major source of the organic carbon was marine [Meyers, 1994]. We thus are confident that changes in benthic foraminiferal $\delta^{13} \mathrm{C}$ we measured are not overprinted by changes in pore water chemistry due to variations in carbon source.

\subsection{Atlantic-Pacific Interbasinal Deep-Sea Carbon Isotopic Gradients}

We evaluated interbasinal deep-sea $\delta^{13} \mathrm{C}$ gradients across the $\mathrm{K} / \mathrm{Pg}$ boundary using the benthic foraminiferal $\delta^{13} \mathrm{C}$ records from Site 1210 (ODP Leg 198, Shatsky Rise, North Pacific; $2574 \mathrm{~m}$ present and $\sim 1500-2000 \mathrm{~m}$ paleodepth) and Site 1262 (ODP Leg 208, Walvis Ridge, South Atlantic; $4759 \mathrm{~m}$ present and $\sim 2500-3000 \mathrm{~m}$ paleodepth). Previously, Alegret et al. [2012] presented the benthic foraminiferal $\delta^{13} \mathrm{C}$ records from these two sites using the astronomically tuned age models of Westerhold et al. [2008] and showed that the benthic foraminiferal $\delta^{13} \mathrm{C}$ gradient between these sites was maintained across the K/Pg boundary (see their Figure 2B).

We used planktonic foraminifera [Bralower et al., 2002; Zachos et al., 2004; Petrizzo et al., 2005] and calcareous nannofossil biostratigraphy [Zachos et al., 2004; Bralower, 2005; Bernaola and Monechi, 2007], as well as magnetostratigraphy [Bowles, 2006; Westerhold et al., 2008], to revise the age calibrations of these two sites (Figures 9 and 10; see Tables S4 and S5 and Text S2 in the supporting information for the datum events used for the age models and the age-depth data tables). We also revised the iron-count tie points that were used in the astronomical time scales of Westerhold et al. [2008] and Hilgen et al. [2010] for a $2.5 \mathrm{Myr}$ time interval after the K/Pg boundary to correlate Site 1210 and Site 1262 in addition to biostratigraphic datum levels (Figure 11). Our age models do not rely on the Fe-counts but only calcareous nannofossil and planktonic foraminiferal datum events and magnetostratigraphy to place age constraints (Figure 11). However, our high-resolution correlation with 14 tie points provides a better fit to the age constraints than the previous correlations [Westerhold et al., 2008; Hilgen et al., 2010] as shown in the Shaw plot (Figure S8; note that the previous correlations fall off the line of correlation and not compatible with the biostratigraphic horizons). Some tie points, namely, 1, 4, 8, and 12, are also projected onto the age-depth 


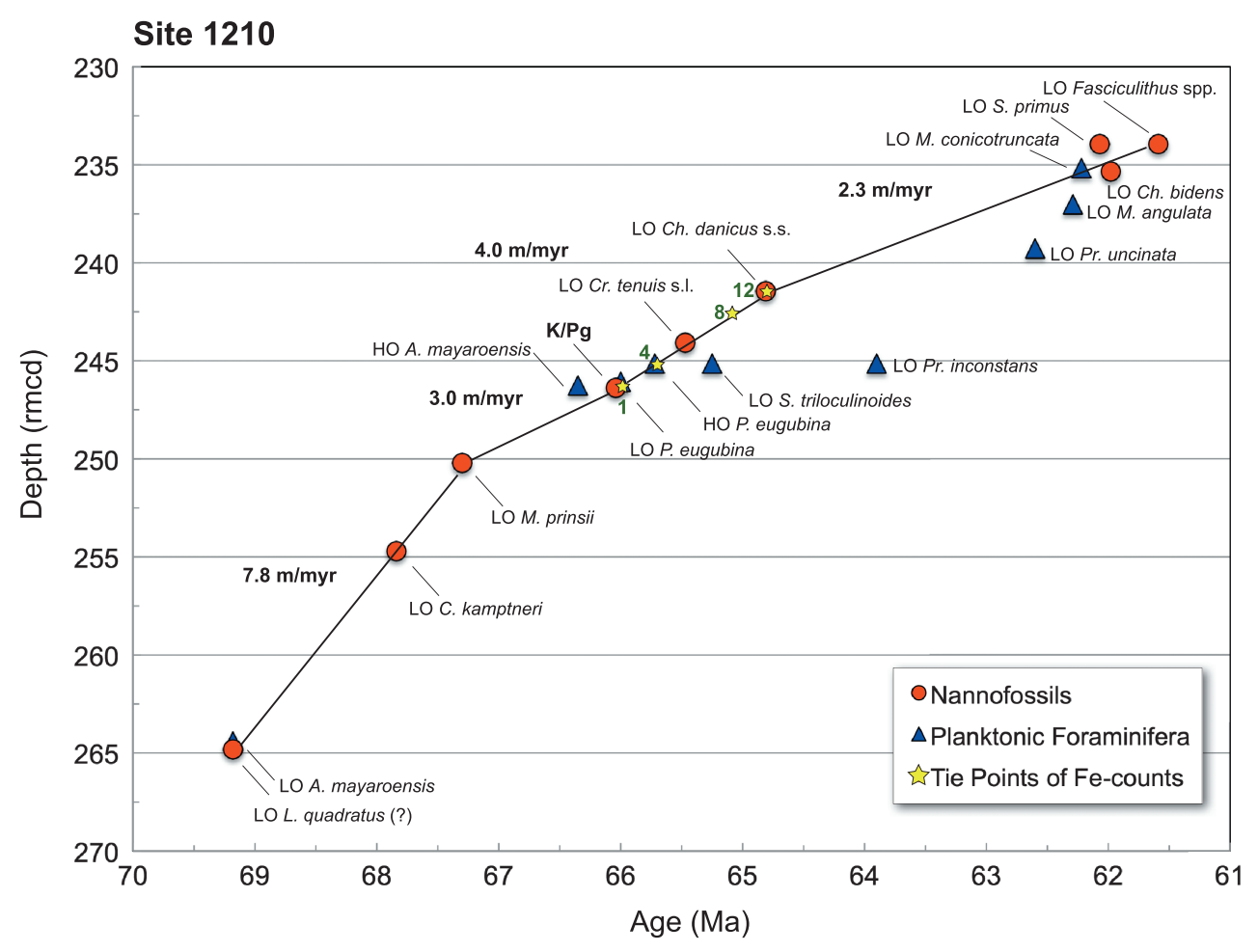

Figure 9. GTS-2012 ages [Gradstein et al., 2012] versus revised meters composite depth (rmcd) [Westerhold and Röhl, 2006] of ODP Leg 198 Site 1210 (North Pacific). Calcareous nannofossils biohorizons (red spheres) are from Bown and Lees [2005] and Bralower [2005] for the Maastrichtian and the Danian, respectively. Planktonic foraminifera biohorizons (blue triangles) are from Bralower et al. [2002] and Petrizzo et al. [2005] for Cretaceous and Paleocene, respectively. LO: Lowest Occurrence. HO: Highest Occurrence. For calcareous nannofossils, L.: Lithraphidites, C.: Ceratolithoides, M.: Micula, Cr.: Cruciplacolithus, Ch.: Chiasmolithus, and S.: Sphenolithus. Nannofossil event LO Fasciculithus spp. is second radiation of Fasciculithus, which is equivalent to the first appearance datum of $F$. ulii. For planktonic foraminifera, A.: Abathomphalus, P.: Parvularugoglobigerina, $S$.: Subbotina, Pr.: Praemurica, and M.: Morozovella. All biohorizons are from Hole A except nannofossil taxa Ch. danicus S.S., which is from Hole B. Sedimentation rates are indicated on the figure. Representative (only 1, 4, 8, and 12) Fe-count tie points of this study (yellow stars) (Figure 11) are projected onto the age-depth plot. There is no magnetostratigraphy data available for Site 1210 for this time interval.

plots of sites in order to show their positions (Figures 9 and 10). Our new age models for Sites 1210 (Figure 9) and 1262 (Figure 10) indicate that the deep-sea benthic foraminiferal $\delta^{13} \mathrm{C}$ gradient between the Atlantic and Pacific Oceans reduced in the early Danian (Figure 11). We note that such reconstructions are sensitive to the age models and our correlations may be subject to further revision; however, they provide an interpretation that reconciles biostratigraphic and magnetostratigraphic constraints.

\section{Discussion}

\subsection{Planktonic Foraminiferal $\delta^{13} \mathrm{C}$ Changes on the Shelf}

Planktonic foraminiferal $\delta^{13} \mathrm{C}$ values at Ancora show a $~ 1 \%$ o gradient ( -0.2 to $-1.2 \%$ ) among newly evolved taxa during Biochron P1a (Figure 8). In the absence of early Danian surface dwellers, this reflects a gradient between intermediate and deep dweller species. We interpret this gradient as reflecting the presence of active mixed layer productivity on the continental shelf $\sim 0.4$ Myr after the mass extinction, which rejects the Strangelove Ocean hypothesis. We cannot comment on the gradients during the earliest Danian (Biozones $\mathrm{PO}$ and $\mathrm{P} \alpha$ ) because the only planktonic taxon available for measurement is $\mathrm{H}$. globulosa.

We measured planktonic foraminiferal species $\mathrm{H}$. globulosa across the $\mathrm{K} / \mathrm{Pg}$ boundary at Ancora, including samples $120 \mathrm{kyr}$ younger than the boundary (Figure 8). H. globulosa is not considered a survivor species of the $\mathrm{K} / \mathrm{Pg}$ mass extinction, and its morphological characteristics indicate that it did not give rise to any Cenozoic foraminifera [Olsson and Liu, 1993; Olsson et al., 1999], though some authors interpret it as a survivor species [Keller, 1988; Pardo and Keller, 2008]. The $\delta^{13} \mathrm{C}$ changes of the species follow the changes 


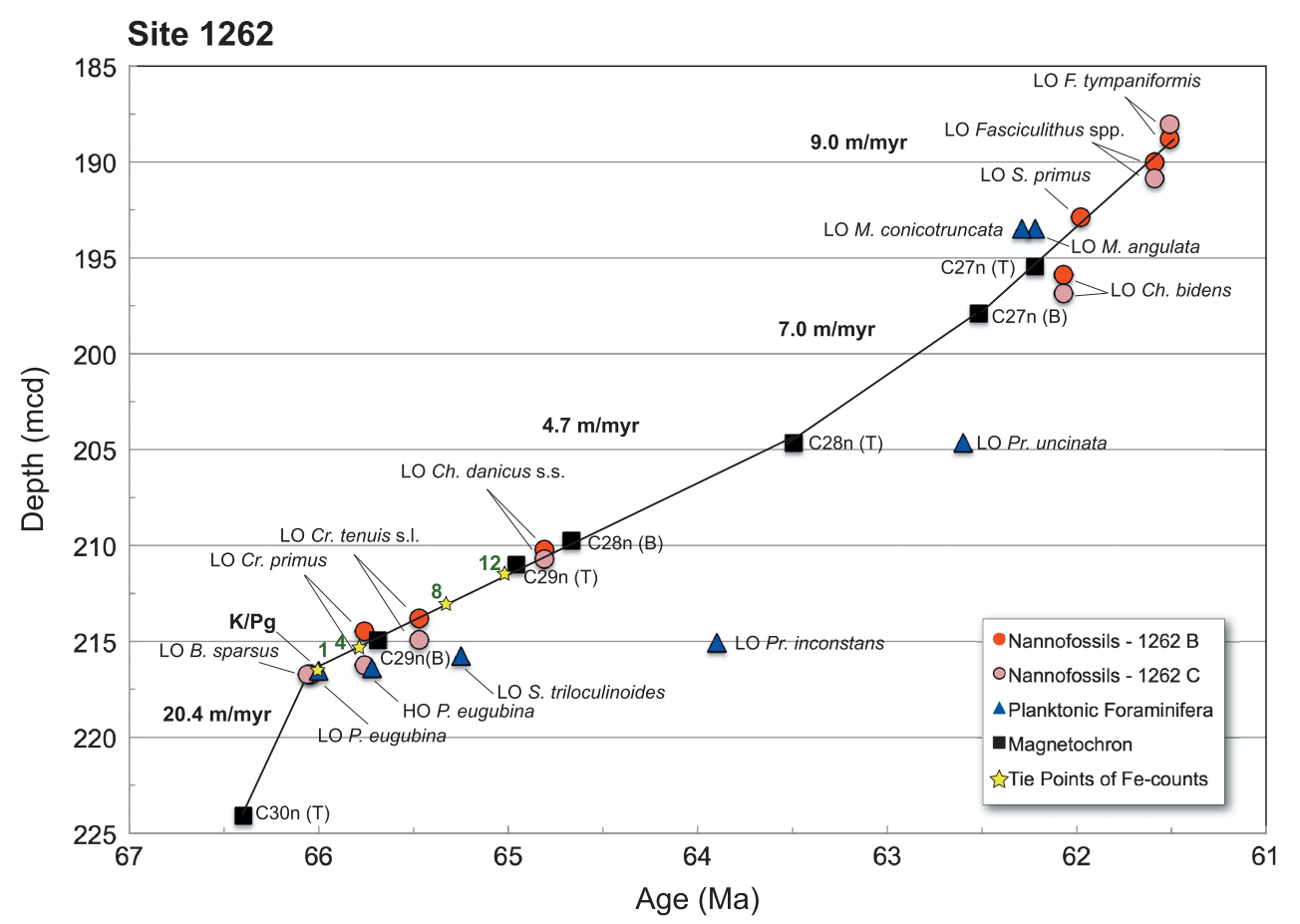

Figure 10. GTS-2012 ages [Gradstein et al., 2012] versus meters composite depth (mcd) of ODP Leg 208 Site 1262 (South Atlantic). Calcareous nannofossils biohorizons from Hole B (red spheres) are from Zachos et al. [2004]. Calcareous nannofossils biohorizons from Hole C (pink spheres) are from Westerhold et al. [2008]. All planktonic foraminifera biohorizons (blue triangles) are from Hole B [Zachos et al., 2004]. LO: Lowest Occurrence. HO: Highest Occurrence. For calcareous nannofossils, Cr.: Cruciplacolithus, Ch.: Chiasmolithus, S.: Sphenolithus, and F.: Fasciculithus. Nannofossil event LO Fasciculithus spp. is second radiation of Fasciculithus, which is equivalent to the first appearance datum of $F$. ulii. For planktonic foraminifera, P.: Parvularugoglobigerina, S.: Subbotina, Pr.: Praemurica, and M.: Morozovella. Depths of magnetochrons are revised depths of Westerhold et al. [2008] from Bowles [2006]. Sedimentation rates are indicated on the figure. Representative (only 1, 4, 8, and 12) Fe-intensity tie points of this study (yellow stars) (Figure 11) are projected onto the age-depth plot.

in the bulk sediment and benthic foraminiferal $\delta^{13} \mathrm{C}$ values at Ancora (Figure 8), and it is possible it survived at least $120 \mathrm{kyr}$ and then became extinct as suggested by Pardo and Keller [2008]. If so, it recorded $\delta^{13} \mathrm{C}$ values of intermediate waters in the earliest Danian, which suggests an $\sim 0.9 \%$ o decrease across the $\mathrm{K} / \mathrm{Pg}$ boundary. However, $\delta^{13} \mathrm{C}$ and $\delta^{18} \mathrm{O}$ cross plots show that $H$. globulosa had similar values in the late Maastrichtian and early Danian (Figure S7), perhaps indicating that $H$. globulosa is reworked rather than in situ in the lowermost Danian. Further analysis of this species across other $\mathrm{K} / \mathrm{Pg}$ boundary locations is warranted.

\subsection{Cross-Shelf Benthic Foraminiferal $\delta^{13} \mathrm{C}$ Gradients}

Early Danian benthic foraminiferal $\delta^{13} \mathrm{C}$ values at Ancora ( 0.5\%) and Bass River ( 1.25\%) indicate that a substantial $\delta^{13} \mathrm{C}$ gradient $(\sim 0.75 \%$ ) developed across the continental shelf following the $\mathrm{K} / \mathrm{Pg}$ event (Figures 3 and 4). This difference might be explained by two possibilities: (1) terrestrial organic carbon influx caused the shallower site (Ancora) to have lower values than the deeper site (Bass River) or (2) a cross-shelf $\delta^{13} \mathrm{C}$ gradient existed between sites in the early Danian. Analyses of $\mathrm{C} / \mathrm{N}$ ratios in both sites, as well as the relationship of $\mathrm{C} / \mathrm{N}$ ratios with $\delta^{13} \mathrm{C}_{\text {org }}$ indicate a primarily marine source with minor terrestrial influence [Meyers, 1994] across the boundary (Figure S6). Therefore, the difference in benthic foraminiferal $\delta^{13} \mathrm{C}$ values is interpreted to reflect stratification in shelf bottom water $\delta^{13} \mathrm{C}$ values between these sites such that the deeper site (Bass River) was far below the DCM and thus recorded higher $\delta^{13} \mathrm{C}$ values than the shallower site (Ancora) (Figures 2 and 3).

The higher values at Bass River indicate that either little or no organic carbon was remineralized in the bottom waters or organic carbon was not exported out of the DCM to the bottom at this site. However, at Ancora benthic foraminiferal $\delta^{13} \mathrm{C}$ values were lower, indicating oxidation of organic carbon in the bottom 


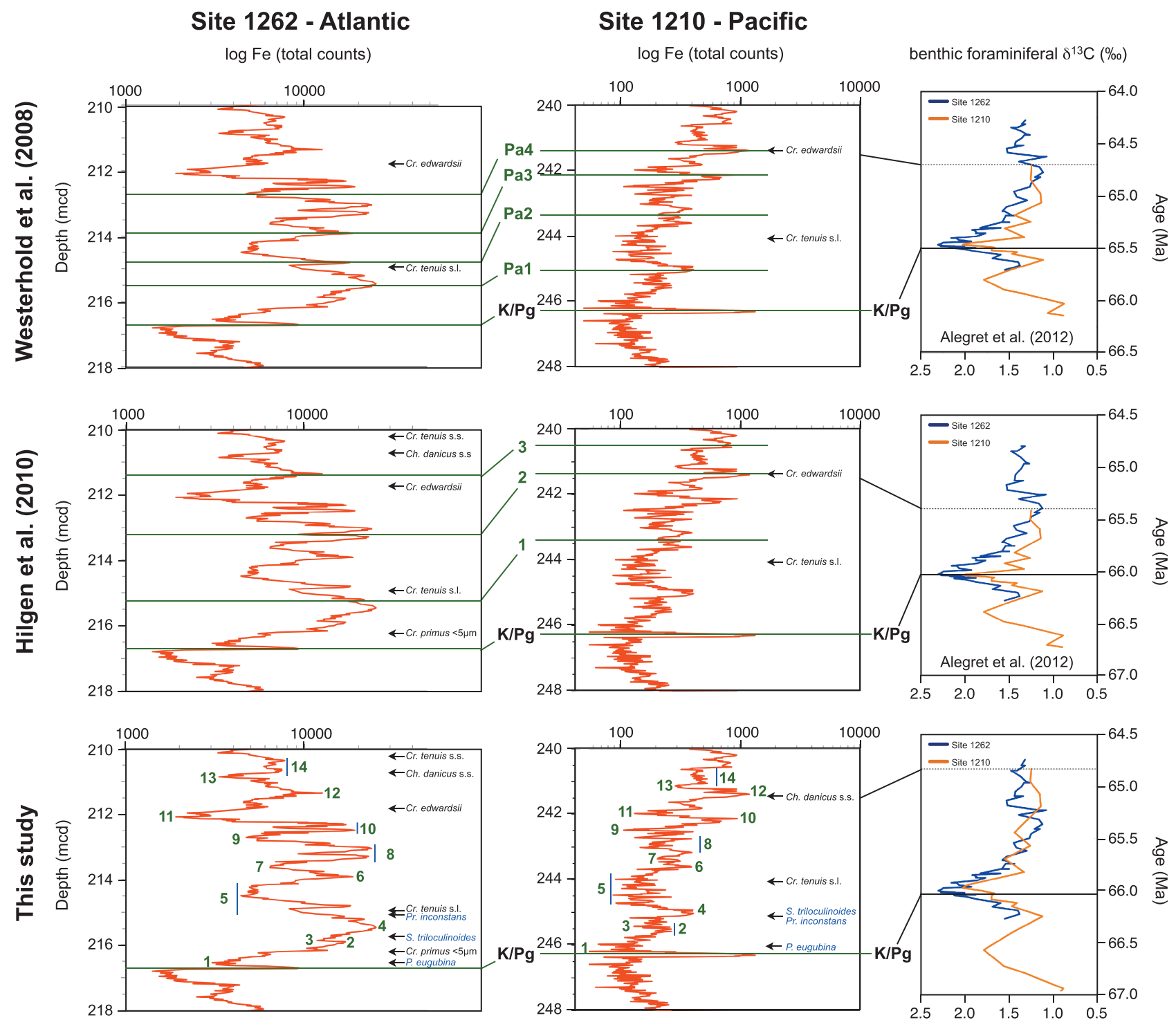

Figure 11. Correlation of ODP Leg 208 Site 1262 (South Atlantic) and ODP Leg 198 Site 1210 (North Pacific) using Fe-counts and biohorizons by Westerhold et al. [2008], Hilgen et al. [2010], and this study and comparison of benthic foraminiferal $\delta^{13} \mathrm{C}$ values [Alegret et al., 2012] based on different age models. Age calibrations for the Maastrichtian both for Westerhold et al. [2008] and Hilgen et al. [2010] are from Alegret et al. [2012]. Depths of Site 1262 and Site 1210 are meters composite depths and revised composite depths [Westerhold and Röhl, 2006], respectively. Tie points (green lines) of Westerhold et al. [2008], namely, Pa1, Pa2, Pa3, and Pa are from their Figure S1. Tie points (green lines) of Hilgen et al. [2010], namely, 1, 2, and 3 are from their Figure 2. Tie points of this study are named from 1 to 14 . Lowest occurrences of calcareous nannofossil and planktonic foraminifera are indicated by black arrows [Zachos et al., 2004; Bralower, 2005; Petrizzo et al., 2005; Westerhold et al., 2008]. For calcareous nannofossils, Cr.: Cruciplacolithus and Ch.: Chiasmolithus. Cr. edwardsii = Ch. danicus s.s. and Cr. tenius s.l. = Cr. intermedius. For planktonic foraminifera, P.: Parvularugoglobigerina, S.: Subbotina, and Pr:: Praemurica.

waters and/or within the sediments. This pattern is interpreted to reflect continued regeneration of organic matter at the shallower site (Ancora) and the reduced export of organic carbon at the deeper site (Bass River). Neither cessation of primary productivity nor maintained export productivity can account for the differences in $\delta^{13} \mathrm{C}$ gradient in bottom waters between Ancora and Bass River. However, such a gradient on a continental shelf is best explained by greatly decreased export productivity predicted by the Living Ocean hypothesis and provides evidence for the presence for an active mixed layer independent of the planktonic foraminiferal $\delta^{13} \mathrm{C}$ values.

\subsection{Deep-Sea Benthic Foraminiferal $\delta^{13} \mathrm{C}$ Gradient}

We test New Jersey paleoshelf implications by considering deep-sea benthic foraminiferal $\delta^{13} \mathrm{C}$ differences between different ocean basins across the $\mathrm{K} / \mathrm{Pg}$ boundary. In case of a global drop in primary and/or 


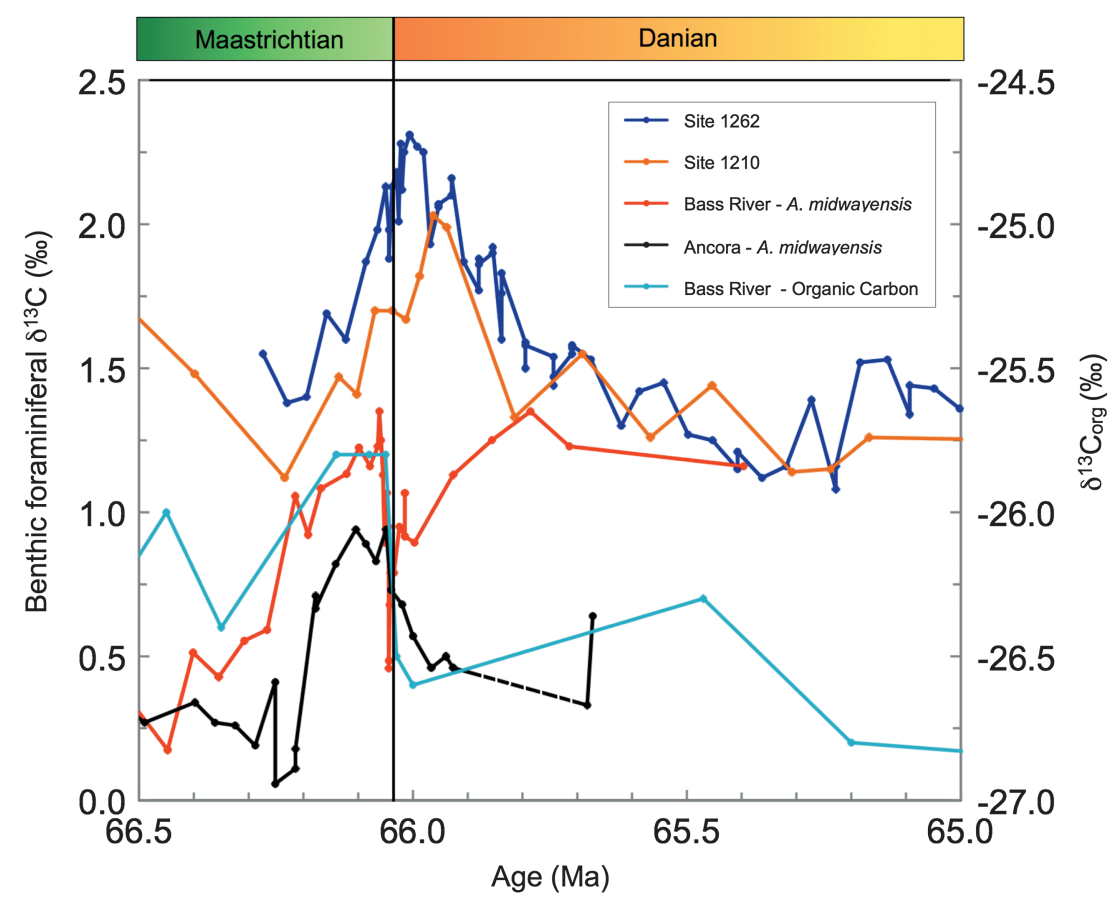

Figure 12. Benthic foraminiferal $\delta^{13} \mathrm{C}$ record of ODP Sites 1262 and 1210 [Alegret et al., 2012], Bass River, and Ancora with the age model of this study. $\delta^{13} \mathrm{C}_{\text {org }}$ record of Bass River is also shown. Dashed line in Ancora curve represents the hiatus between Biozones P $\alpha$ and P1a.

export productivity the interbasinal deep-sea benthic foraminiferal $\delta^{13} \mathrm{C}$ gradient would collapse in the early Danian, whereas maintained global export productivity predicts that the gradient should remain relatively constant across the $\mathrm{K} / \mathrm{Pg}$ boundary.

The age model of Westerhold et al. [2008], which was used by Alegret et al. [2012], and the revised age model of Hilgen et al. [2010] show that the benthic foraminiferal $\delta^{13} \mathrm{C}$ gradient was maintained after the K/Pg boundary between the South Atlantic and North Pacific (Figure 11), supporting persistent export productivity across the $\mathrm{K} / \mathrm{Pg}$ boundary. However, these two age models based on astronomical tuning are inconsistent with the biostratigraphic events for the first $2.5 \mathrm{Myr}$ interval after the K/Pg boundary (Figures 11 and S8). Our new age models for the sites based on biostratigraphy and magnetostratigraphy, also supported independently by the Fe-count correlation, show that the benthic foraminiferal $\delta^{13} \mathrm{C}$ gradient was reduced (Figure 11), indicating a decrease in global export productivity in agreement with the New Jersey paleoshelf data.

Although there are uncertainties in our age model, our correlation of two sites based on biostratigraphy and magnetostratigraphy is more compatible than the previous correlations that used astronomical tuning (Figure 12). Even though our age model will not be the final say on Danian correlations of Atlantic and Pacific sites, it calls into question previous interpretations of Alegret et al. [2012] showing persistent interbasinal benthic foraminiferal $\delta^{13} \mathrm{C}$ gradients after the $\mathrm{K} / \mathrm{Pg}$ boundary and demonstrates that such interpretations strongly depend on the age models (Figure 11).

\subsection{Productivity in the Aftermath of the K/Pg Extinction}

The survivorship of deep sea benthic foraminifera across the K/Pg boundary was explained by a persistent food supply to the ocean floor [Alegret and Thomas, 2009; Alegret et al., 2012]. However, the significant drop in bulk $\delta^{13} \mathrm{C}$ values, the low percentages and low accumulation rates of total organic carbon, and reverse gradient between planktonic and benthic foraminiferal $\delta^{13} \mathrm{C}$ values after the $\mathrm{K} / \mathrm{Pg}$ boundary are best explained by a significant drop in organic carbon burial. Even though benthic foraminifera survived the K/Pg boundary [Culver, 2003], the diversity of benthic foraminiferal assemblages decreased after the $\mathrm{K} / \mathrm{Pg}$ boundary in the Pacific and Atlantic Oceans as well as in Tethyan sections indicating high environmental stress [Alegret and Thomas, 2005]. While Pacific Ocean sites (DSDP Site 465, ODP 1210) 
show an increase in benthic foraminiferal accumulation rates and infaunal taxa after the $\mathrm{K} / \mathrm{Pg}$ boundary (indicative of a high food supply to the ocean floor), Southern Ocean (Site 690) and South Atlantic (Site 1262) sites show little change or a decrease in benthic foraminiferal accumulation rates and infaunal taxa percentages, interpreted as low export productivity after the $\mathrm{K} / \mathrm{Pg}$ boundary [Alegret et al., 2012].

It has been shown that there is a spatial heterogeneity in the magnitude and direction of the change in export productivity among oceanic sites [Hull and Norris, 2011; Sibert et al., 2014], even though the mechanism responsible for this heterogeneity is not clear [Hull and Norris, 2011]. Geochemical proxies indicate that Atlantic sites except coastal and upwelling sites like Blake Nose and Fish Clay, Denmark, show a decrease in export productivity, whereas some Pacific sites like Hess Rise (DSDP Site 465) and Shatsky Rise (ODP Site 1210) indicate a brief increase in export productivity [Hull and Norris, 2011] in agreement with the benthic foraminiferal proxies [Alegret and Thomas, 2009]. This geographic heterogeneity recorded in the change in export productivity after the $\mathrm{K} / \mathrm{Pg}$ boundary is also in line with the heterogeneous response of different ecosystems to the mass extinction. It has been shown that different communities responded to the perturbations differently; while some groups suffered great turnovers, some groups survived the K/Pg boundary and even thrived in some regions [Hollis et al., 1995; Jablonski, 1998; Sogot et al., 2013].

The New Jersey paleoshelf data and our interbasinal deep-sea $\delta^{13} \mathrm{C}$ comparisons are most consistent with the Living Ocean hypothesis suggesting a reduction in global export productivity. However, we acknowledge that export productivity in some areas may have changed very little and this heterogeneity in response (Heterogeneous Ocean) points to the complexity of reconstructing productivity variations globally

\subsection{Carbon Cycle Changes}

Comparisons of deep-sea records with New Jersey paleoshelf data have important implications related to the long- and short-term changes in the carbon cycle spanning the $\mathrm{K} / \mathrm{Pg}$ boundary. During the late Maastrichtian, there was a long-term ( $500 \mathrm{kyr}$, longer than residence time of carbon, which is $\sim 180 \mathrm{kyr}$ in modern oceans) increase in benthic foraminiferal $\delta^{13} \mathrm{C}$ values both in the deep-sea sections [Alegret et al., 2012] and in the New Jersey paleoshelf (Figure 12). This indicates a gradual increase in the organic carbon relative to carbonate carbon burial toward the $\mathrm{K} / \mathrm{Pg}$ boundary or a change in the $\delta^{13} \mathrm{C}$ of weathering input. After the $\mathrm{K} / \mathrm{Pg}$ boundary, a long-term decrease in $\delta^{13} \mathrm{C}$ of surface-dwelling planktonic foraminifera, deep-dwelling benthic foraminifera, and bulk sediments occurs in the deep-sea sections [Zachos and Arthur, 1986; Zachos et al., 1989] (Figure 12). This could be likely attributed to a decrease in global organic carbon burial relative to carbonate carbon in the early Danian associated with productivity reduction in surface waters. We note that benthic foraminiferal $\delta^{13} \mathrm{C}$ values increase at Bass River in the early Danian (66.0-65.8 Ma; Figure 12) in contrast to globally decreasing values; this also suggests the absence of export productivity at Bass River.

The magnitude of $\delta^{13} \mathrm{C}$ decrease in benthic foraminifera varies at different locations. For example, shelf sections show a sharp benthic foraminiferal $\delta^{13} \mathrm{C}$ decrease at the $\mathrm{K} / \mathrm{Pg}$ boundary and subsequently appear to follow the long-term deep-sea $\delta^{13} \mathrm{C}$ decrease (Figure 12). The sharp shelf benthic foraminiferal $\delta^{13} \mathrm{C}$ decrease and lower $\delta^{13} \mathrm{C}$ values of benthic foraminifera in the shelf than in the deep-sea sections can be attributed to at least three possible causes: (1) input of more terrestrial organic carbon input on the shelf; we reject this hypothesis based on $\mathrm{C} / \mathrm{N}$ ratios that show a decrease across K/Pg boundary (Figure S6), suggesting less terrestrial organic matter input in the early Danian; (2) more organic carbon burial on the shelf; we reject this hypothesis based on our measurements that show a decrease in MAR- $C_{\text {org }}$ (Figure 8); and (3) shoaling of the oxygen minimum zone where organic carbon is regenerated. With a long-term decrease in the organic carbon burial shoaling of the oxygen minimum zone is predicted, and thus, our data support this explanation.

It is more difficult to estimate short-term (less than the residence time of carbon) global $\delta^{13} \mathrm{C}$ seawater changes across $\mathrm{K} / \mathrm{Pg}$ boundary. Deep-sea benthic foraminiferal $\delta^{13} \mathrm{C}$ values show a short-term increase of $0.8 \%$ ofter a $\sim 50 \mathrm{kyr}$ lag (Figure 12) [Alegret et al., 2012], which can be interpreted as reflecting a decrease in organic carbon oxidation at the sediment/water interface and deep water as a result of a reduction in surface water production [Kump, 1991; Kump and Arthur, 1999]. The short-term change of the benthic foraminiferal $\delta^{13} \mathrm{C}$ values across the $\mathrm{K} / \mathrm{Pg}$ boundary at the Bass River seems to be different than the 
change at Ancora and the deep-sea sites. While other sites show a boundary crossing increase in $\delta^{13} \mathrm{C}$ values of benthic foraminifera, Bass River shows a transient decrease. This difference can be attributed to the better representation of the $\mathrm{K} / \mathrm{Pg}$ event at Bass River than the other sites with in situ impact spherules, clay clasts, and Iridium anomaly [Olsson et al., 1997, 2002].

Planktonic foraminifera $\delta^{13} \mathrm{C}$ values show a short-term decrease of $\sim 2 \%$ in deep-sea locations across the $\mathrm{K} / \mathrm{Pg}$ boundary transition and in the earliest Danian [Zachos and Arthur, 1986; Zachos et al., 1989]. Bulk sediments also show a drop of 2-3\% in deep-sea sections [Alegret et al., 2012] and a 2-2.5\%o decrease in New Jersey shelf cores. Both suggest reduction in organic carbon production in surface waters. However, the decrease in $\delta^{13} \mathrm{C}_{\text {org }}$ across the $\mathrm{K} / \mathrm{Pg}$ boundary transition in New Jersey shelf is only $0.8 \%$ o. This suggests that the bulk carbonate $\delta^{13} \mathrm{C}$ change may overestimate seawater changes in $\delta^{13} \mathrm{C}$, supporting Alegret et al.'s [2012] suggestion that the large bulk $\delta^{13} \mathrm{C}$ decrease is at least partly an artifact of the turnover. However, changes in $\delta^{13} \mathrm{C}_{\text {org }}$ are highly variable in different $\mathrm{K} / \mathrm{Pg}$ boundary locations [Meyers, 1992]. The difference in the inorganic and organic carbon can be associated with the local differences in the biosynthetic pathways, biochemical constitutions and species compositions that influence the organic matter [Meyers, 1992]. We conclude that the transient, short-term $(<100 \mathrm{kyr}) \delta^{13} \mathrm{C}$ response to the $\mathrm{K} / \mathrm{Pg}$ boundary is still uncertain.

\section{Conclusions}

Integration of paleoshelf and deep-sea isotopic records provides constraints on global carbon budget changes across the $\mathrm{K} / \mathrm{Pg}$ boundary. Updip-downdip comparison of Ancora (paleodepth of $70 \pm 10 \mathrm{~m}$ ) and Bass River (paleodepth of $\sim 110 \pm 20 \mathrm{~m}$ ) provides a unique opportunity to test productivity and export productivity changes regarding to the perturbations of the carbon cycle after the $\mathrm{K} / \mathrm{Pg}$ mass extinction. Detailed isotopic measurements on the shelf indicate a decrease in bulk carbonate and organic carbon $\delta^{13} \mathrm{C}$ values, as well as mass accumulation rates of organic carbon. Similar to deep-sea isotope records, paleoshelf data show that the vertical $\delta^{13} \mathrm{C}$ gradient between planktonic and benthic foraminifera collapsed, the trophic structure of the planktonic foraminifera in the water column was altered, and no planktonic foraminifera occupied the surface layer in the early Danian. Perturbations seen both in the paleocontinental shelf and deep-sea locations can be attributed to reduced primary and/or export productivity after the $\mathrm{K} / \mathrm{Pg}$ boundary event. However, a $\sim 1.0 \%$ o water column $\delta^{13} \mathrm{C}$ gradient in planktonic foraminifera and a $\sim 0.75 \%$ o cross-shelf $\delta^{13} \mathrm{C}$ gradient in benthic foraminifera in the early Danian measured in the shelf indicate the presence of active primary productivity, strongly supporting the Living Ocean hypothesis. Though New Jersey data do not contradict the Heterogeneous Ocean, the apparent drop in Atlantic to Pacific interbasinal deep-sea $\delta^{13} \mathrm{C}$ based on our new age model is the most consistent with a drop in global export productivity predicted by the Living Ocean hypothesis. Uniformity in the change of export productivity in the world shelves and deep-sea oceans cannot be expected; the ocean floor in highly productive regions like the equatorial Pacific may have continued to receive significant export productivity.

Acknowledgments

Data and figures supporting the manuscript are in the supporting information. Samples from Ancora and Bass River coreholes were provided by the Integrated Ocean Drilling Program (IODP); cores are archived at the IODP Rutgers core repository. This work is supported by NSF grants EAR 070778 (K.G. Miller) and OCE-0961914 (T.M. Quan). We thank P. Falkowski for discussions, E. Thomas for a review of a draft of this manuscript, and two anonymous reviewers for their suggestions.

\section{References}

Alegret, L., and E. Thomas (2005), Cretaceous/Paleogene boundary bathyal paleo-environments in the central North Pacific (DSDP Site 465), the Northwestern Atlantic (ODP Site 1049), the Gulf of Mexico and the Tethys: The benthic foraminiferal record, Palaeogeogr. Palaeoclimatol. Palaeoecol., 224(1-3), 53-82, doi:10.1016/j.palaeo.2005.03.031.

Alegret, L., and E. Thomas (2009), Food supply to the seafloor in the Pacific Ocean after the Cretaceous/Paleogene boundary event, Mar. Micropaleontol., 73(1-2), 105-116, doi:10.1016/j.marmicro.2009.07.005.

Alegret, L., E. Thomas, and K. C. Lohmann (2012), End-Cretaceous marine mass extinction not caused by productivity collapse, Proc. Natl. Acad. Sci. U.S.A., 109(3), 728-732, doi:10.1073/pnas.1110601109/-/DCSupplemental/ST01.doc.

Bemis, B. E., and H. J. Spero (1998), Reevaluation of the oxygen isotopic composition of planktonic foraminifera: Experimental results and revised paleotemperature equations, Paleoceanography, 13(2), 150-160, doi:10.1029/98PA00070.

Berggren, W. A., and P. Pearson (2005), A revised tropical to subtropical Paleogene planktonic foraminiferal zonation, J. Foraminiferal Res., 35(4), 279-298.

Bernaola, G., and S. Monechi (2007), Calcareous nannofossil extinction and survivorship across the Cretaceous-Paleogene boundary at Walvis Ridge (ODP Hole 1262C, South Atlantic Ocean), Palaeogeogr. Palaeoclimatol. Palaeoecol., 255(1-2), 132-156, doi:10.1016/j.palaeo.2007.02.045.

Birch, H. S., H. K. Coxall, and P. N. Pearson (2012), Evolutionary ecology of Early Paleocene planktonic foraminifera: Size, depth habitat and symbiosis, Paleobiology, 38(3), 374-390, doi:10.5061/dryad.5p92t38g.

Boersma, A., and N. J. Shackleton (1981), Oxygen- and carbon-isotope variations and planktonic-foraminifer depth habitats, Late Cretaceous to Paleocene, Central Pacific, Deep Sea Drilling Project Sites 463 and 465, Initial Rep. Deep Sea, 62, 513-526.

Bornemann, A., and R. D. Norris (2007), Size-related stable isotope changes in Late Cretaceous planktic foraminifera: Implications for paleoecology and photosymbiosis, Mar. Micropaleontol., 65(1-2), 32-42, doi:10.1016/j.marmicro.2007.05.005. 
Bowles, J. (2006), Data report: Revised magnetostratigraphy and magnetic mineralogy of sediments from Walvis Ridge, Leg 208, Proc. Ocean Drill. Prog. Sci. Results, 208, 1-24.

Bralower, T. J. (2005), Data report: Paleocene-Early Oligocene calcareous nannofossil biostratigraphy, ODP Leg 198 Sites 1209, 1210, and 1211 (Shatsky Rise, Pacific Ocean), Proc. Ocean Drill. Prog. Sci. Results, 198, 1-15.

Bralower, T. J., I. Premoli Silva, and M. J. Malone (2002), Site 1210, Proc. Ocean Drill. Program Initial Rep., 198, 1-89.

Broecker, W. S., and T. H. Peng (1982), Tracers in the Sea, pp. 620, Lamont-Doherty Geological Observatory Columbia Univ. Press, Palisades, New York. Browning, J. V., K. G. Miller, and R. K. Olsson (1997), Lower to middle Eocene benthic foraminiferal biofacies and lithostratigraphic units and their relationship to sequences, New Jersey Coastal Plain, Proc. Ocean Drill. Prog. Sci. Results, 150X, 207-228.

Browning, J. V., K. G. Miller, P. J. Sugarman, J. Barron, F. M. G. McCarthy, D. K. Kulhanek, M. E. Katz, and M. D. Feigenson (2013), Chronology of Eocene-Miocene sequences on the New Jersey shallow shelf: Implications for regional, interregional, and global correlations, Geosphere, 9(6), 1434-1456, doi:10.1130/GES00857.S1.

Coplen, T. B., C. Kendall, and J. Hopple (1983), Comparison of stable isotope reference samples, Nature, 302(5905), 236-238, doi:10.1038/ $302236 \mathrm{a} 0$.

Coplen, T. B., W. A. Brand, M. Gehre, M. Gröning, H. A. J. Meijer, B. Toman, and R. M. Verkouteren (2006), New guidelines for $\delta^{13} \mathrm{C}$ measurements, Anal. Chem., 78(7), 2439-2441, doi:10.1021/ac052027c.

Coxall, H. K., S. D'Hondt, and J. C. Zachos (2006), Pelagic evolution and environmental recovery after the Cretaceous-Paleogene mass extinction, Geology, 34(4), 297-300, doi:10.1130/G21702.1.

Craig, H. (1965), The measurement of oxygen isotope paleotemperatures, in Proceedings of the Spoleto Conference on Stable Isotopes in Oceanographic Studies and Paleotemperatures, edited by E. Tongiorgi, pp. 161-182, Consiglio Nazionale delle Ricerche, Pisa.

Cullen, J. J. (1982), The deep chlorophyll maximum: comparing vertical profiles of chlorophyll a, Can. J. Fish. Aquat. Sci., 39, 791-803.

Culver, S. (2003), Benthic foraminifera across the Cretaceous-Tertiary (K-T) boundary: A review, Mar. Micropaleontol., 47(3-4), 177-226.

Degens, E. T. (1969), Biogeochemistry of Stable Carbon Isotopes in Organic Geochemistry Methods and Results, edited by G. Eglinton and M. T. J. Murphy, Chap. 12, pp. 304-328, Springer, Berlin, Heidelberg.

D'Hondt, S. (2005), Consequences of the Cretaceous/Paleogene mass extinction for marine ecosystems, Annu. Rev. Ecol. Evol. Syst., 36(1), 295-317.

D'Hondt, S., and J. C. Zachos (1993), On stable isotopic variation and earliest Paleocene planktonic foraminifera, Paleoceanography, 8(4), 527-547, doi:10.1029/93PA00952.

D'Hondt, S., and J. C. Zachos (1998), Cretaceous foraminifera and the evolutionary history of planktic photosymbiosis, Paleobiology, 24(4), $512-523$.

D'Hondt, S., P. Donaghay, J. C. Zachos, D. Luttenberg, and M. Lindinger (1998), Organic carbon fluxes and ecological recovery from the Cretaceous-Tertiary mass extinction, Science, 282(5387), 276-279, doi:10.1126/science.282.5387.276.

Emiliani, C. (1954), Depth habitats of some species of pelagic foraminifera as indicated by oxygen isotope ratios, Am. J. Sci., 252, 149-158.

Epstein, S., R. Buchsbaum, H. A. Lowenstam, and H. C. Hurey (1953), Revised carbonate-water isotopic temperature scale, Geol. Soc. Am. Bull., 64, 1315-1326.

Esmeray-Senlet, S., S. Ozkan-Altiner, D. Altiner, and K. G. Miller (2015), Planktonic foraminiferal biostratigraphy, microfacies analysis and sequence stratigraphy across the Cretaceous/Paleogene boundary in the Haymana Basin, Central Anatolia, Turkey, J. Sediment. Res., 85, 489-508, doi:10.2110/jsr.2015.31.

Fairbanks, R. G., and P. H. Wiebe (1980), Foraminifera and chlorophyll maximum: Vertical distribution, seasonal succession, and paleoceanographic significance, Science, 209(4464), 1524-1526.

Glenn, S., C. Jones, M. Twardowski, L. Bowers, J. Kerfoot, J. Kohut, D. Webb, and O. Schofield (2008), Glider observations of sediment resuspension in a Middle Atlantic Bight fall transition storm, Limnol. Oceanogr., 53, 2180-2196.

Gradstein, F. M., J. G. Ogg, M. Schmitz, and G. Ogg (2012), The Geologic Time Scale 2012 2-Volume Set, vol. 1-2, pp. 1176, Elsevier BV, Oxford.

Harris, A. D., K. G. Miller, J. V. Browning, P. J. Sugarman, R. K. Olsson, B. S. Cramer, and J. D. Wright (2010), Integrated stratigraphic studies of Paleocene-lowermost Eocene sequences, New Jersey Coastal Plain: Evidence for glacioeustatic control, Paleoceanography, 25, PA3211, doi:10.1029/2009PA001800

Hay, W. W., and S. Floegel (2012), New thoughts about the Cretaceous climate and oceans, Earth Sci. Rev., 115(4), 262-272, doi:10.1016/ j.earscirev.2012.09.008.

Hickman, A. E., P. M. Holligan, C. M. Moore, J. Sharples, V. Krivtsov, and M. R. Palmer (2009), Distribution and chromatic adaptation of phytoplankton within a shelf sea thermocline, Limnol. Oceanogr., 54(2), 525-536.

Hilgen, F. J., K. F. Kuiper, and L. J. Lourens (2010), Evaluation of the astronomical time scale for the Paleocene and earliest Eocene, Earth Planet. Sc. Lett., 300(1-2), 139-151, doi:10.1016/j.epsl.2010.09.044.

Hollis, C. J., K. A. Rodgers, and R. J. Parker (1995), Siliceous plankton bloom in the earliest Tertiary of Marlborough, New Zealand, Geology, 23(9), 835-838.

Hsu, K., Q. He, J. McKenzie, H. Weissert, K. Perch-Nielsen, H. Oberhansli, K. Kelts, J. LaBrecque, L. Tauxe, and U. Krahenbuhl (1982), Mass mortality and its environmental and evolutionary consequences, Science, 216(4543), 249-256.

Huber, B. T., K. G. MacLeod, and N. A. Tur (2008), Chronostratigraphic framework for upper Campanian-Maastrichtian sediments on the Blake Nose (subtropical North Atlantic), J. Foraminiferal Res, 38(2), 162-182.

Hull, P. M., and R. D. Norris (2011), Diverse patterns of ocean export productivity change across the Cretaceous-Paleogene boundary: New insights from biogenic barium, Paleoceanography, 26, PA3205, doi:10.1029/2010PA002082.

Jablonski, D. (1998), Geographic variation in the molluscan recovery from the end-Cretaceous extinction, Science, 279(5355), 1327-1330.

Keller, G. (1988), Extinction, survivorship and evolution of planktic foraminifera across the Cretaceous/Tertiary boundary at El Kef, Tunisia, Mar. Micropaleontol., 13(3), 239-263.

Kim, S.-T., and J. R. O'Neil (1997), Equilibrium and nonequilibrium oxygen isotope effects in synthetic carbonates, Geochim. Cosmochim. Acta, 61(16), 3461-3475.

Kominz, M. A., and S. F. Pekar (2001), Oligocene eustasy from two-dimensional sequence stratigraphic backstripping, Geol. Soc. Am. Bull., 113(3), 291-304.

Kopp, R. E., D. Schumann, T. D. Raub, D. S. Powars, L. V. Godfrey, N. L. Swanson-Hysell, A. C. Maloof, and H. Vali (2009), An Appalachian Amazon? Magnetofossil evidence for the development of a tropical river-like system in the mid-Atlantic United States during the Paleocene-Eocene thermal maximum, Paleoceanography, 24, PA4211, doi:10.1029/2009PA001783.

Koutsoukos, E. (1996), Phenotypic experiments into new pelagic niches in early Danian planktonic foraminifera: Aftermath of the K/T boundary event, Geol. Soc. Spec. Publ., 102(1), 319-335.

Kroopnick, P. M. (1985), The distribution of ${ }^{13} \mathrm{C}$ of $\Sigma \mathrm{CO}_{2}$ in the world oceans, Deep-Sea Res., 32(1), 57-84. 
Kump, L. R. (1991), Interpreting carbon-isotope excursions: Strangelove oceans, Geology, 19(4), 299-302.

Kump, L. R., and M. Arthur (1999), Interpreting carbon-isotope excursions: Carbonates and organic matter, Chem. Geol., 161(1-3), 181-198. Lees, P. R., and J. A. Bown (2005), Upper Cretaceous calcareous nannofossil biostratigraphy, ODP Leg 198 (Shatsky Rise, Northwest Pacific Ocean), Proc. Ocean Drill. Prog. Sci. Results, 198, 1-60.

Meyers, P. A. (1992), Changes in organic carbon stable isotope ratios across the K/T boundary: Global or local control?, Chem. Geol. Isot. Geosci. Sec., 101(3), 283-291.

Meyers, P. A. (1994), Preservation of elemental and isotopic source identification of sedimentary organic matter, Chem. Geol., 114(3), 289-302. Miller, K. G., et al. (1998), Bass River Site, in Proceedings of the Ocean Drilling Program, Initial Rep., vol. 174AX, edited by K. G. Miller, P. J. Sugarman, and J. V. Browning, pp. 5-43, Ocean Drilling Program, College Station, Tex.

Miller, K. G., et al. (1999), Ancora Site, in Proceedings of the Ocean Drilling Program, Initial Rep., vol. 174AX, edited by K. G. Miller, P. J. Sugarman, and J. V. Browning, pp. 1-65, Ocean Drilling Program, College Station, Tex.

Miller, K. G., R. Sherrell, J. V. Browning, M. Field, W. Gallagher, R. K. Olsson, P. J. Sugarman, S. Tuorto, and H. Wahyudi (2010), Relationship between mass extinction and iridium across the Cretaceous-Paleogene boundary in New Jersey, Geology, 38(10), 867-870, doi:10.1130/ G31135.1.

Mouw, C. B., and J. A. Yoder (2005), Primary production calculations in the Mid-Atlantic Bight, including effects of phytoplankton community size structure, Limnol. Oceanogr., 50(4), 1232-1243.

Müller, R. D., M. Sdrolias, C. Gaina, B. Steinberger, and C. Heine (2008), Long-term sea-level fluctuations driven by ocean basin dynamics, Science, 319(5868), 1357-1362, doi:10.1126/science.1151540.

Norris, R. D. (1996), Symbiosis as an evolutionary innovation in the radiation of Paleocene planktic foraminifera, Paleobiology, 22, 461-480.

Ohkouchi, N., J. Kuroda, M. Okada, and H. Tokuyama (2003), Why Cretaceous black shales have high C/N ratios: Implications from SEM-EDX observations for Livello Bonarelli black shales at the Cenomanian-Turonian boundary, Earth Evol., 1, 239-241.

Olsson, R. K., and C. Liu (1993), Controversies on the placement of Cretaceous-Paleogene boundary and the K/P mass extinction of planktonic foraminifera, Palaios, 8, 127-139.

Olsson, R. K., and E. Nyong (1984), A paleoslope model for Campanian-lower Maestrichtian foraminifera of New Jersey and Delaware, J. Foraminiferal Res, 14(1), 50-68.

Olsson, R. K., K. G. Miller, J. V. Browning, D. Habib, and P. J. Sugarman (1997), Ejecta layer at the Cretaceous-Tertiary boundary, Bass River, New Jersey (Ocean Drilling Program Leg 174AX), Geology, 25(8), 759-762.

Olsson, R. K., C. Hemleben, W. A. Berggren, B. T. Huber, and Editors and Members of the Paleogene Planktonic Foraminifera Working Group (1999), Atlas of Paleocene Planktonic Foraminifera, Smithson. Contrib. Paleobiol., 85, 252.

Olsson, R. K., J. D. Wright, and K. G. Miller (2001), Paleobiogeography of Pseudotextularia elegans during the latest Maastrichtian global warming event, J. Foraminiferal Res., 31(3), 275-282.

Olsson, R. K., K. G. Miller, J. V. Browning, J. D. Wright, and B. S. Cramer (2002), Sequence stratigraphy and sea-level change across the Cretaceous-Tertiary boundary on the New Jersey passive margin, Geol. Soc. Spec. Publ., 356, 97-108.

O'Neil, J. R. (1969), Oxygen isotope fractionation in divalent metal carbonates, J. Chem. Phys., 51(12), 5547-5558, doi:10.1063/1.1671982.

Pardo, A., and G. Keller (2008), Biotic effects of environmental catastrophes at the end of the Cretaceous and early Tertiary: Guembelitria and Heterohelix blooms, Cretaceous Res., 29(5-6), 1058-1073, doi:10.1016/j.cretres.2008.05.031.

Pearson, P., P. Ditchfield, J. Singano, K. Harcourt-Brown, C. Nicholas, R. K. Olsson, N. J. Shackleton, and M. Hall (2001), Warm tropical sea surface temperatures in the Late Cretaceous and Eocene epochs, Nature, 413, 481-487.

Petrizzo, M. R., I. Premoli Silva, and P. Ferrari (2005), Data report: Paleogene planktonic foraminifer biostratigraphy, ODP Leg 198 Holes $1209 A$, 1210A, and 1211A (Shatsky Rise, Northwest Pacific Ocean), Proc. Ocean Drill. Prog. Sci. Results, 198, 1-56.

Pingree, R. D., P. M. Holligan, G. T. Mardell, and R. N. Head (1976), The influence of physical stability on spring, summer and autumn phytoplankton blooms in the Celtic Sea, J. Mar. Biol. Ass., 56(04), 845-873, doi:10.1017/S0025315400020919.

Premoli Silva, I., and D. Verga (2004), Practical Manual of Cretaceous Planktonic Foraminifera. International School on Planktonic Foraminifera, 3. Course: Cretaceous, edited by D. Verga and R. Rettori, pp. 283, Univ. of Perugia and Milan, Tipografia Pontefelcino, Perugia Italy.

Premuzic, E. T., C. M. Benkovitz, J. S. Gaffney, and J. J. Walsh (1982), The nature and distribution of organic matter in the surface sediments of world oceans and seas, Org. Geochem., 4(2), 63-77, doi:10.1016/0146-6380(82)90009-2.

Quan, T. M., B. van de Schootbrugge, M. P. Field, Y. Rosenthal, and P. G. Falkowski (2008), Nitrogen isotope and trace metal analyses from the Mingolsheim core (Germany): Evidence for redox variations across the Triassic-Jurassic boundary, Global Biogeochem. Cycles, 22, GB2014 doi:10.1029/2007GB002981.

Raup, D., and J. Sepkoski Jr. (1982), Mass extinctions in the marine fossil record, Science, 215(4539), 1501-1503.

Ryan, J. P., J. A. Yoder, and P. C. Cornillon (1999), Enhanced chlorophyll at the shelfbreak of the Mid-Atlantic Bight and Georges Bank during the spring transition, Limnol. Oceanogr., 44(1), 1-11.

Sampei, Y., and E. Matsumoto (2001), C/N ratios in a sediment core from Nakaumi Lagoon, southwest Japan-usefulness as an organic source indicator, Geochem. J., 35(3), 189-205.

Schulte, P., L. Alegret, I. Arenillas, J. A. Arz, P. Barton, P. Bown, T. J. Bralower, G. Christeson, P. Claeys, and C. Cockell (2010), The Chicxulub asteroid impact and mass extinction at the Cretaceous-Paleogene boundary, Science, 327(5970), 1214-1218.

Shackleton, N. J. (1974), Attainment of isotopic equilibrium between ocean water and the benthonic foraminifera genus Uvigerina: Isotopic changes in the ocean during the last glacial, Colloq. Int. C.N.R.S, 219, 203-209.

Shackleton, N. J., and J. P. Kennett (1975), Paleotemperature history of the Cenozoic and the initiation of Antarctic glaciation, oxygen and carbon isotope analyses in DSDP Sites 277, 279, and 281, in Initial Reports of the Deep Sea Drilling Project, vol. 29, edited by J. P. Kennett, pp. 743-755, U.S. Government Printing Office, Washington, D. C.

Sharples, J., C. M. Moore, T. P. Rippeth, P. M. Holligan, D. J. Hydes, N. R. Fisher, and J. H. Simpson (2001), Phytoplankton distribution and survival in the thermocline, Limnol. Oceanogr., 46(3), 486-496.

Sibert, E. C., P. M. Hull, and R. D. Norris (2014), Resilience of Pacific pelagic fish across the Cretaceous/Palaeogene mass extinction, Nat. Geosci., 7(9), 667-670, doi:10.1038/ngeo2227.

Smit, J. (1982), Extinction and evolution of planktonic foraminifera after a major impact at the Cretaceous/Tertiary boundary, Geol. Soc. Spec Publ., 190, 329-352.

Sogot, C. E., E. M. Harper, and P. D. Taylor (2013), Biogeographical and ecological patterns in bryozoans across the Cretaceous-Paleogene boundary: Implications for the phytoplankton collapse hypothesis, Geology, 41(6), 631-634, doi:10.1130/G34020.1.

Steckler, M., G. S. Mountain, K. G. Miller, and N. Christie-Blick (1999), Reconstruction of Tertiary progradation and clinoform development on the New Jersey passive margin by 2-D backstripping, Mar. Geol., 154(1-4), 399-420. 
Stott, L. D., and J. P. Kennett (1989), New constraints on early Tertiary palaeoproductivity from carbon isotopes in foraminifera, Nature, 342 , 526-529.

Volk, T., and M. I. Hoffert (1985), Ocean carbon pumps: Analysis of relative strengths and efficiencies in ocean-driven atmospheric $\mathrm{CO}_{2}$ changes, in The Carbon Cycle and Atmospheric CO2: Natural Variations Archean to Present, vol. 32, edited by E. T. Sundquist and W. S. Broecker, pp. 99-110, AGU, Washington, D. C.

Wade, B. S., and P. N. Pearson (2008), Planktonic foraminiferal turnover, diversity fluctuations and geochemical signals across the Eocene/Oligocene boundary in Tanzania, Mar. Micropaleontol., 68(3-4), 244-255, doi:10.1016/j.marmicro.2008.04.002.

Westerhold, T., and U. Röhl (2006), Data report: Revised composite depth records for Shatsky Rise Sites 1209, 1210, and 1211, Proc. Ocean Drill. Prog. Sci. Results, 198, 1-26.

Westerhold, T., U. Röhl, I. Raffi, E. Fornaciari, S. Monechi, V. Reale, J. Bowles, and H. Evans (2008), Astronomical calibration of the Paleocene time, Palaeogeogr. Palaeoclimatol. Palaeoecol., 257(4), 377-403.

Zachos, J. C., and M. Arthur (1986), Paleoceanography of the Cretaceous/Tertiary boundary event: Inferences from stable isotopic and other data, Paleoceanography, 1(1), 5-26, doi:10.1029/PA001i 001 p00005.

Zachos, J. C., M. Arthur, and W. Dean (1989), Geochemical evidence for suppression of pelagic marine productivity at the Cretaceous/Tertiary boundary, Nature, 337(6202), 61-64.

Zachos, J. C., M.-P. Aubry, W. A. Berggren, T. Ehrendorfer, F. Heider, and K. Lohmann (1992), 54. Chemobiostratigraphy of the Cretaceous/Paleocene boundary at Site 750, Southern Kerguelen Plateau, Proc. Ocean Drill. Prog. Sci. Results, 120, $961-977$.

Zachos, J. C., D. Kroon, and P. Blum (2004), Site 1262, Proc. Ocean Drill. Program Initial Rep., 208, 1-90.

Zapecza, O. S. (1984), Hydrogeologic framework of the New Jersey coastal plain, U.S. Geol. Surv. Open File Rep., 84(730), 1-61. 